\title{
التطبيقات المعاصرة لعقد التأمين التعاوني في ضوء القواعد الفقهية (البنك الإسالامي الأردني وشركة التأمين الإسالامية المساهمة المحدودة أنموذجاً)

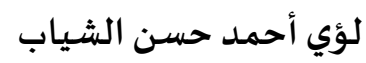

اختصاصي تدريب تربية إسلامية- وزارة التربية والتعليم- الإمارات العربية المتحدة

Loiyahmad314@yahoo.com

\author{
محمد أحمد عواد الرواشدة \\ أستاذ الدراسات الفقهية والقانونية- جامعة مؤته- الأردن \\ Dr-rawashdeh-60@hotmail.com
}

DOI: https://doi.org/DOI:10.31559/sis2020.4.1.2

القواعد الفقهية: حفظ الفروع الكثيرة بالألفاظ القليلة ولأن الفروع تشعبت وتناثرت وتكاثرت فيحتاج الطالب لأن يجمع

نظائرها.

وأما عن التَّأمين التَّعاونيّ بشكلّ عام: فهو نظامٌ اجتماعيٌّ يقوم على مبدأ التعاون والتكافل بين أفراد المجتمع، هدفه تخفيف

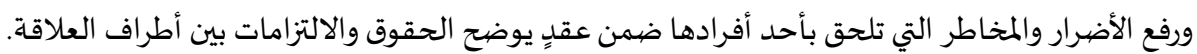

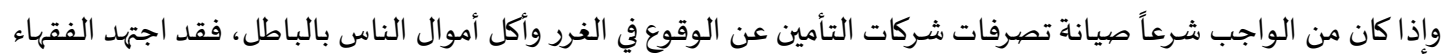
في محاولة تصحيح العقود التأمينية الصادرة عن الشركات من خلال وضع الضيوابط والشروط الصحيحة الصيحة، وقد اعتمد الفقهاء على

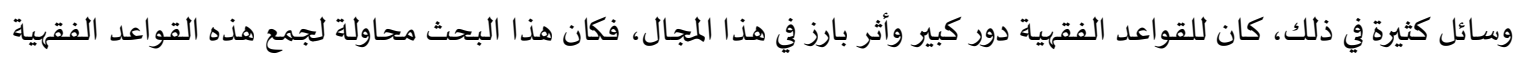
التي اعتمد علهها الفقهاء في تصحيح تصرفات شركات التأمين الإسلامية من البطلان، ومن ثم بيان التطبيقات العمات العملية التي يمارسها كل

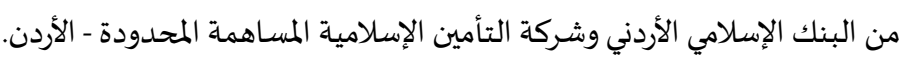
الكلمات المفتاحية: القواعد الفقهية؛ التأمين التعاوني؛ التطبيقات المعاصرة. (9) (1)

الإطار النّظريّ وأدبيّات الدّراسـة

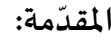

الحمد لله وإن كان يقل مع حق جلاله حمد الحامدين. وأشهد أن لا إله إلا الله وحده لا شريك له. وأشهد أن سيدنا ونبينا محمداً

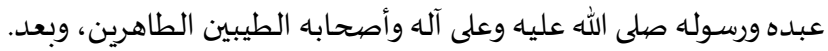

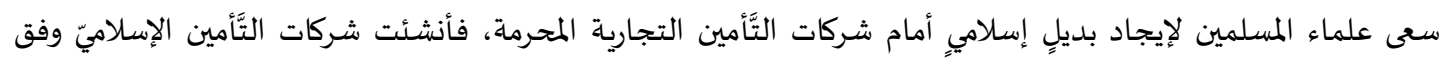

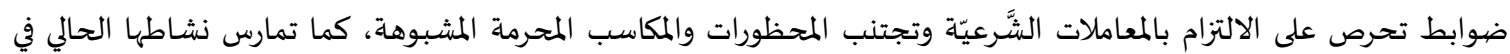

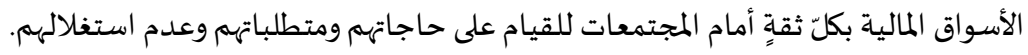

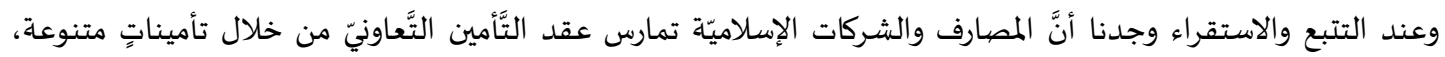

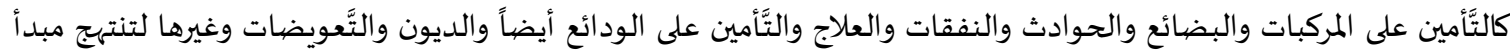

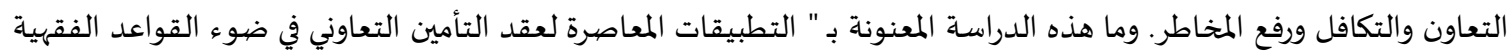

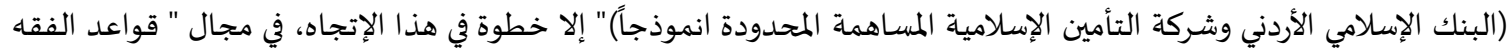
الإسلامي" خاصة، ، إذ إنها تحاول تحديد" ما يترتب على تصرفات الشركات بناءً على القواعد في الفقه الإسلامي". 
وقد جاءت دراستنا هذه في البحث على مبحثين: الأول: تعريف القواعد والضيوابط الفقهية، وبيان أهميتها، والثاني: دور القواعد الفقهية في الحكم على تصرفات شركات التأمين الإسلامية.

مشكلة الدراسـة: - مش: تحاول هذه الدراسـة بيانِ العقود المتعلقة بعقد التأمين التعاوني في البنك الإسلامي الأردني وشركة التأمين الإسلامية في ضوء القواعد الفقهية. أسئلةُ البحثث:

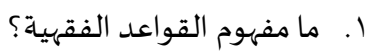

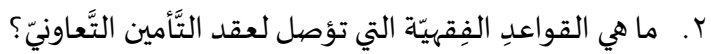

أهميةُ البحث:

إن الثورة الاقتصادية المعاصرة لا سيما التقدم المذهل في عالم المعاملات المالية والمصرفية يدفع بالمسلم إلى النظر في منظومة

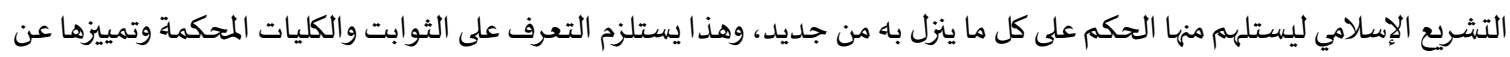
التغيرات والجزئيات التي يسوغ فيها تجدد النظر والاجتهاد؛ ومن المعاملات المصرفية المتجدددة عقد التأمين التعاوني الذي يحوي التهي

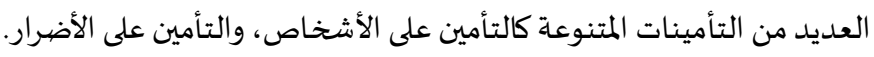

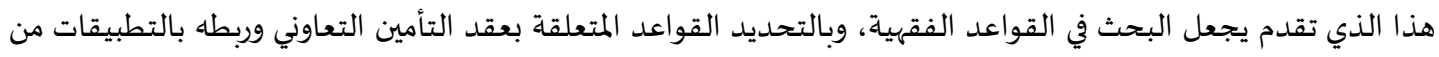

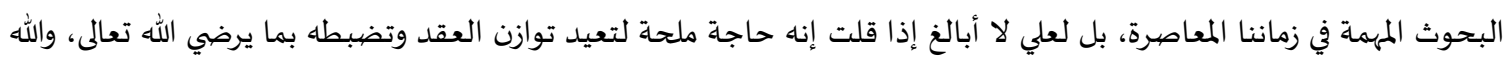
يهدف البحث إلى التعرف على مفهومي القواعد الفقهية وعقد التأمين التعاوني، وتخريج عقد التأمين التعاوني وفق القواعد الفقهية من خلال إظهار العلاقة بينهما. منهرج البحث: قام هذا البحث على المنهج الاستقرائي والمنهج الاستنباطي من خلال: • جمع المادة العلمية وبسط الآراء ومناقشتها. تخريج القواعد الفقهية المتعلقة بعقد التأمين التعاوني.

الدراسات السابقة: أما عن الدراسات السابقة التي تنحو هذا المنحى فقليلة جداً - في حدود استقراء الباحثان - على الرغم من كثرة الدراسات التي

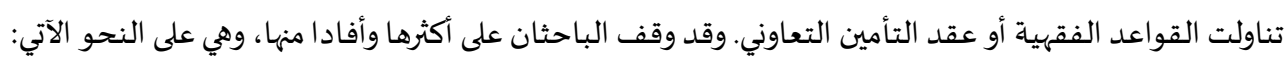

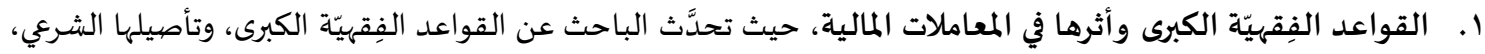

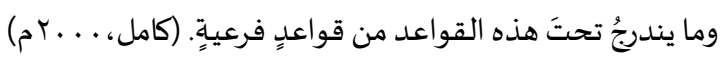

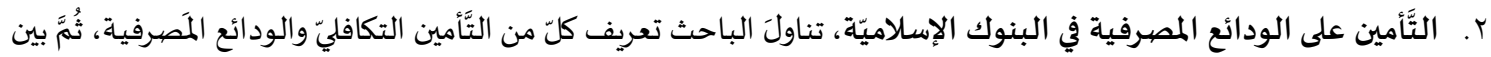
أهمية ضمان الودائع المصرفية والمخاطر التي دعت إلى ذلك، وكيفية مواجهتها وصهولاً إلى توضيح صهور التَّأمين على الودائع

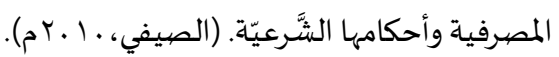

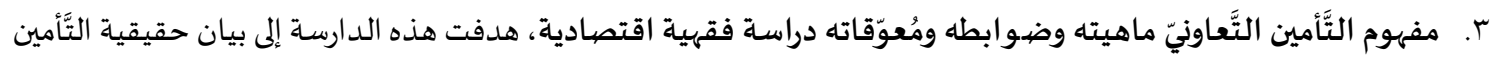

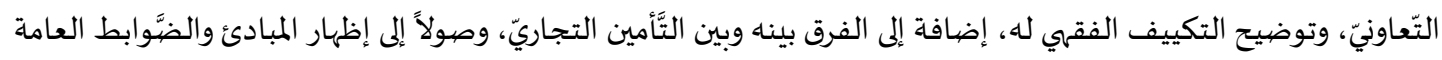

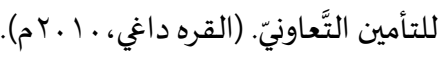

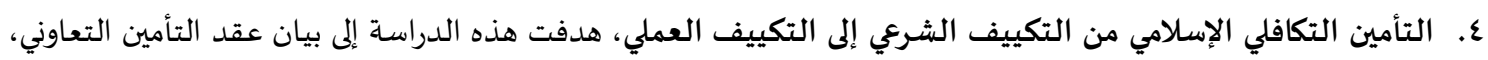

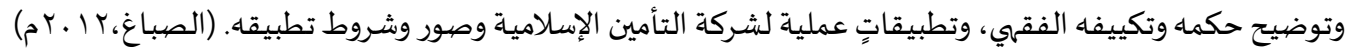


الدراسات السابقة تتفق مع دراستنا في تناول حقيقية التأمين التعاوني وخاصة التكييف الفقهي والحكم الشرعي وبعض إتصات

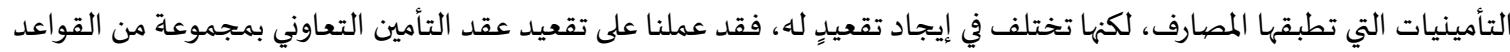
الفقهية لجمع الفروع الكثير بالألفاظ القليلة.

خطة البحث: اقتضت طبيعة البحث أن يتكون من مقدمة وثلاثة مباحث وخاتمة على النحو الآتي: المبحث الأول: القواعد والضـوابط الفقهية، تعريفها، أهميتها

المطلب الأول: تعريف القواعد والضوابط الفقهية. المطلب الثاني: أهمية القواعد الفقهية.

المبحث الثاني: حقيقة عقد التأمين التعاوني، تعريفه، والتكييف الفقهي وحجيته. المطلب الأول: تعريف عقد التأمين التعاوني. المطلب الثاني: التكييف الفقهي لعقد التأمين التعاوني وحجيتاه.

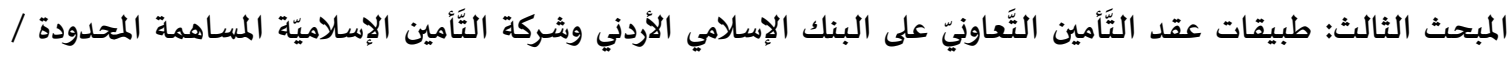
الأردن، في ضوء القواعد الفِقهيّة. المطلب الأول: التأمين على المركبات.

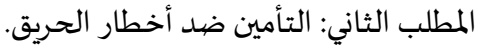
المطلب الثالث: التأمين الصبي (نفقات العلاج). المطلب الرابع: التأمين على الحياة. المطلب الخامس: التأمين على الودائع. المطلب السادس: التأمين على الديون. الخاتمة: وتتضمن النتائج والتوصيات.

المبحث الأول: القواعد والضـوابط الفقهية، تعريفهما، أهميتهما المطلب الأول: تعريف القواعد والضهوابط الفقهية

ا ـ تعريف القاعدة الفِقهيّة:

هي قضيّة كلية شرعية عمليّة جزئياتها قضايا كلية شرعية عملية (الباحسين، 10 ـ ب م). r. تعريف الضـابط الفقهي:

ما انتظم صوراً متشابهة في موضوع فقهي واحد غير ملتفت فيه إلى معنى جامع مؤثر (الباحسين، 0 ـ م م).

المطلب الثاني: أهمية القواعد الفقهية إن للقواعد الفقهية الكثيرَ من الفوائد والأهمية؛ منها: حفظ الفروع الكثيرة بالألفاظ القليلة، وتكوين الملكة الفقهية لدى

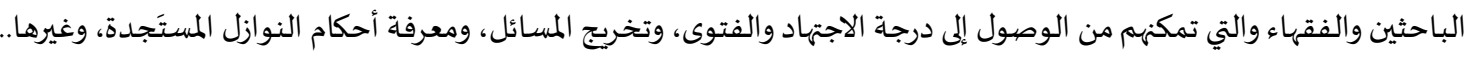
لذلك يقول القرافي: " وهذه القواعد مهمة في الفقاه، عظيمة النفع، وبقدر الإحاطة بها يعظم قدر الفقيه ويَشرف، ويظهر الفهر رونق الفقه ويُعرف، وتتضح مناهج الفتاوى وتُكشف، فيها تنافس العلماء، وتفاضل الفضلاء... (القرافي، ول199 م). ويقول صاحب المنثور في القواعد للإمام الزركشي الشافعي:" فإن ضبط الأمور المنتشرة المتعددة في القوانين المتحدة هو أوعى وتهي لحفظها وأدعى لضبطها.." (الزركشي، ... . ب م).

المبحث الثاني: حقيقة عقد التأمين التعاوني، تعريفه، والتكييف الفقهي وحجيته المطلب الأول: تعريف عقد التأمين التعاوني 
أوّلَا: التَّأمين لغة: مشتق من مادة " أمن" الهمزة والميم والنون أصلان متقاربان: أحدهما الأمانة التي هي ضدّ الخيانة، ومعناها سكون

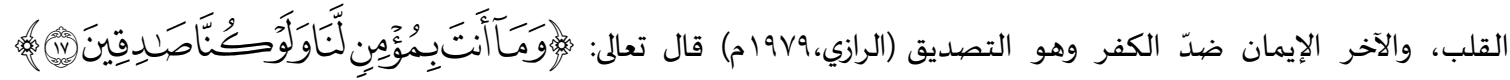

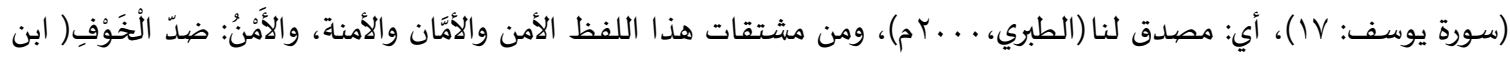

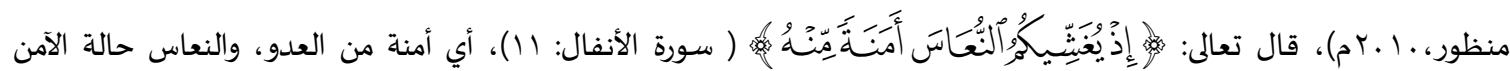
الذي لا يخاف ( القرطبي، ع79 ام)، ومن هذا الاشتقاق أخذ تعريف التَّأمين.

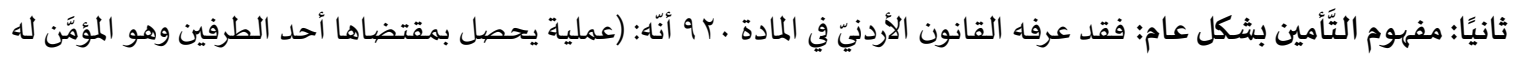
نظير قسط على تعهد لصالحها، أو لصالح غيره من الطرف الآخر، وهو المؤمن على تعهد بمقتضياه يدفع هذا الأخير أداءً معينًا عند تحقق الخطر المعين، وذلك عن طريق تجميع مجموع من المخاطر وإجراء المقاصة وفقًا لقوانين الإحصاء) (القانون المدني

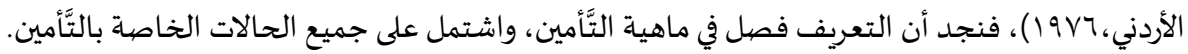

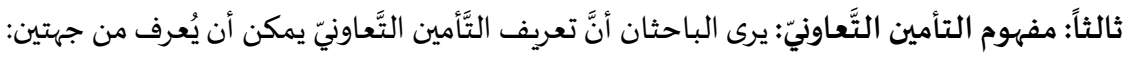

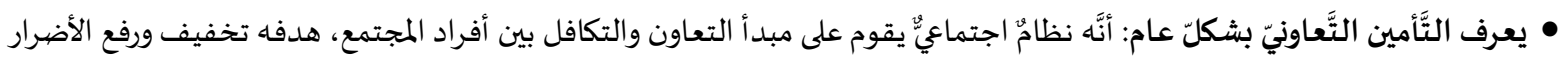
والمخاطر التي تلحق بأحد أفرادها ضمن عقدٍ يوضح الحقوق والالتزامات بين أطراف العلاقة.

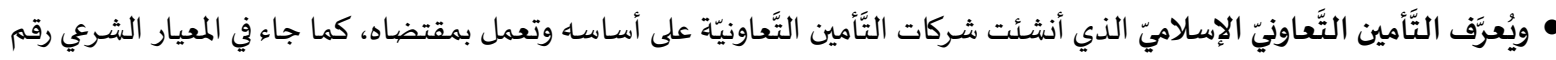
( (r): هو اتِفاق أشخاص يتعرضون لأخطار معينة على تلافي الأضرار الناشئة عن هذه الأخطار؛ وذلك بدفع اشتراكات على أساس الألتزام

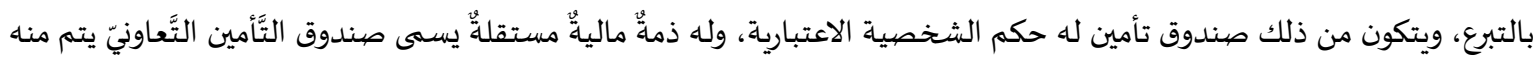

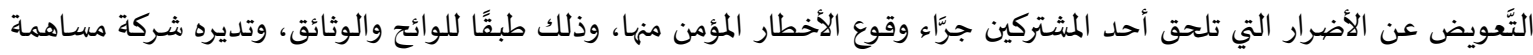

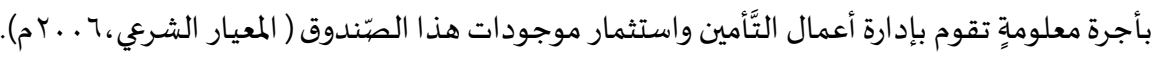

المطلب الثاني: التكييف الفقهي لعقد التأمين التعاوني وحكمه

أولاً: التكييف الفقهي لعقد التأمين التعاوني:

ثَمََّّة اجتهادات صيدرت من الفقهاء المعاصرين حول التكييف الفقهي لعقد التَّأمين التَّعاونيّ، فمنهم من جعل عقد التَّامين يقوم

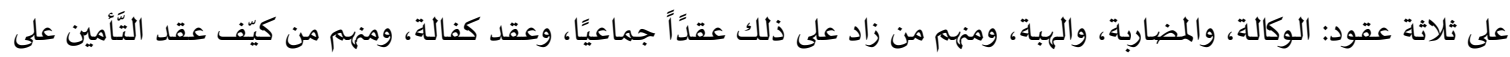

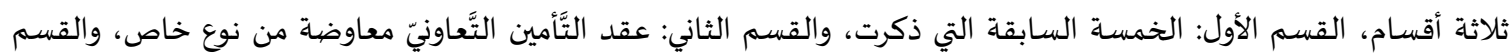

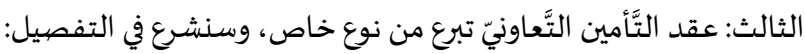

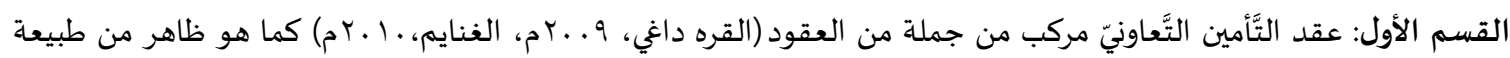

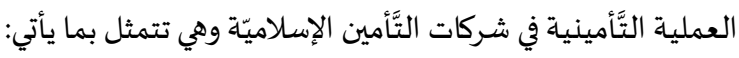

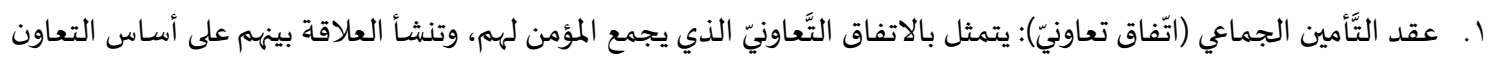
والتبادل، وتحمُّل المخاطر والآثار التي تلحق بأحدهم، ويكون التزامًا جماعيًا.

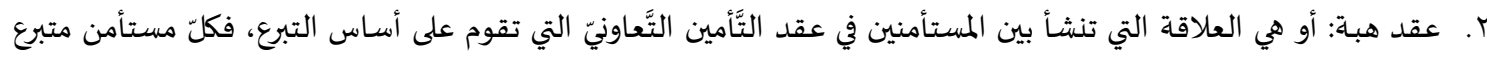

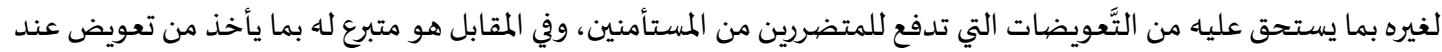
تضرره. r. عقد وكـالة: العلاقة التي ينظمها الوكيل (شركة التَّأمين أو من ينوب عنهم) وبين المستأمنين (الموكلّين)، وبموجبه تقوم الشركة بإدارة العمليات التَّأمينية نيابةً عن المستأمنين.

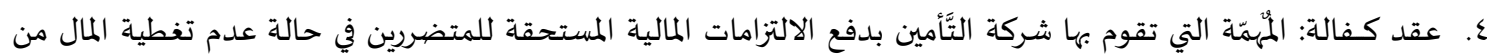

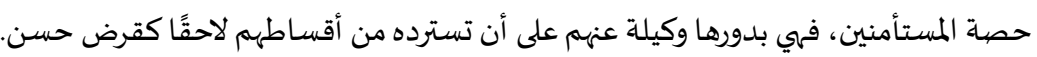

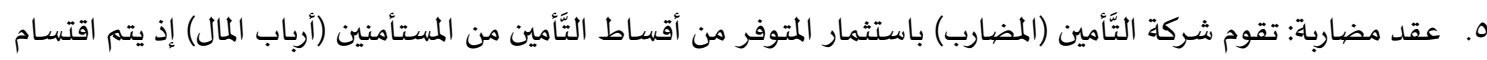
الأرباح فيما بينهم حسب الاتفاق، شريطة أن يكون الاستثُمار بالطرق المشروعة، يضاف من إلى ذلك نصيب كلّ من الشركة إلى حساب المساهمين، ويضاف نصيب المستأمنين إلى جملة أقساط التَّأمين التي يملكونها. 


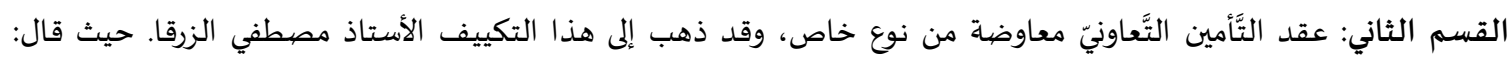

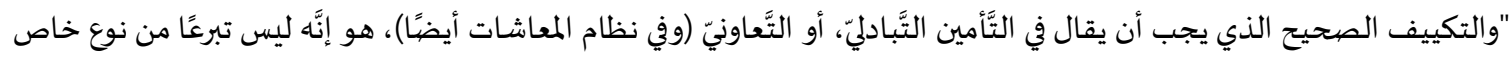

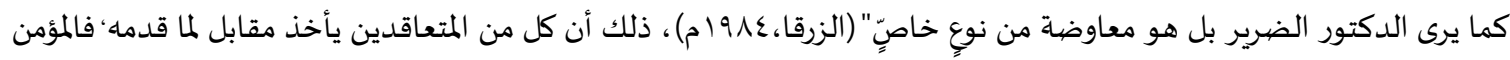

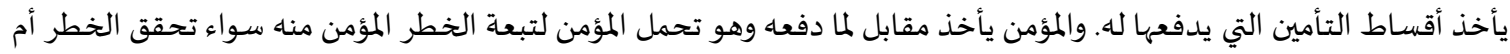

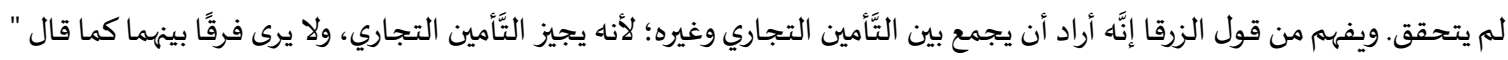

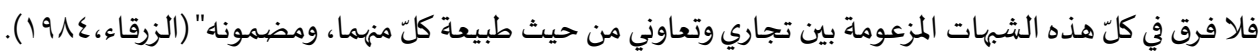

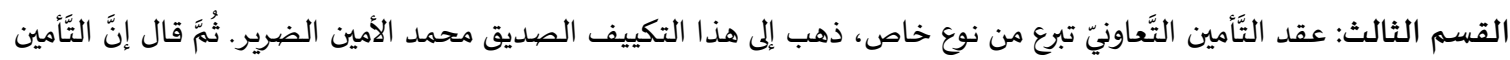

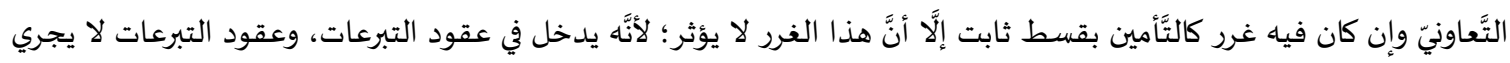

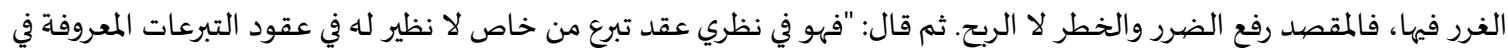

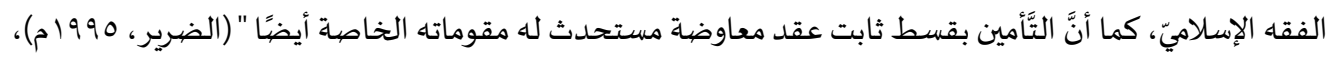

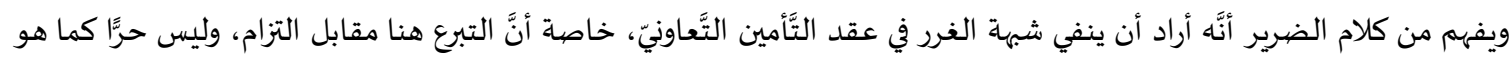

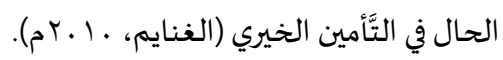

الترجيع والمناقشة:

يرى الباحثان أنَّ القسم الأول هو المناسب للتكييف الفقهي لعقد التَّأمين التَّعاونيّ؛ ذلك لأنَّهَ تتداخل فيه جملة من العقود

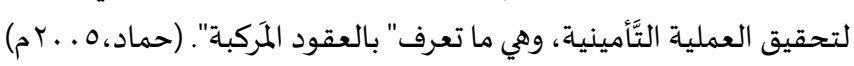

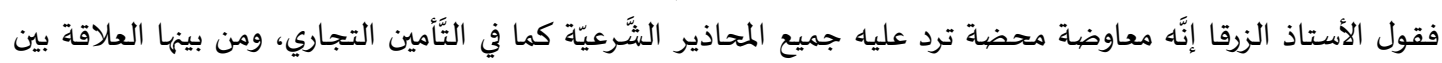

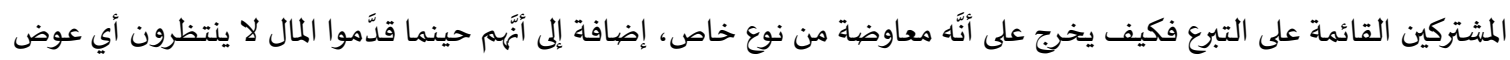

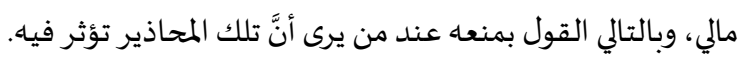

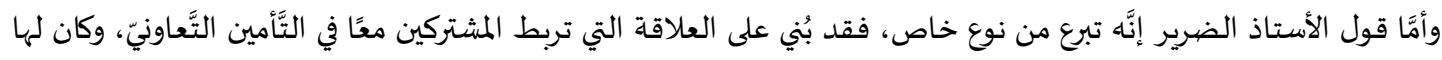

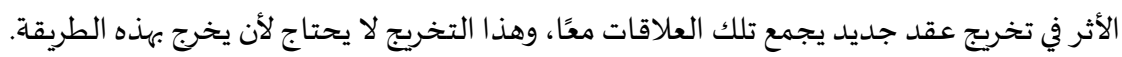

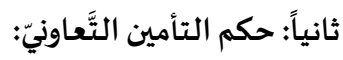

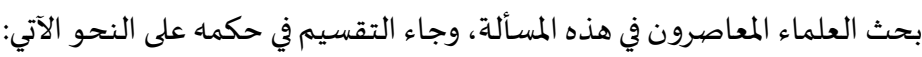

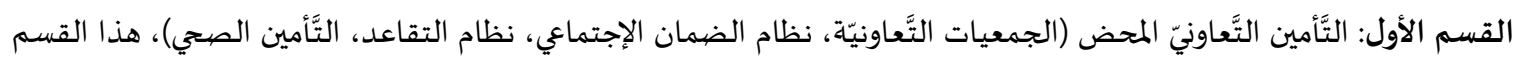

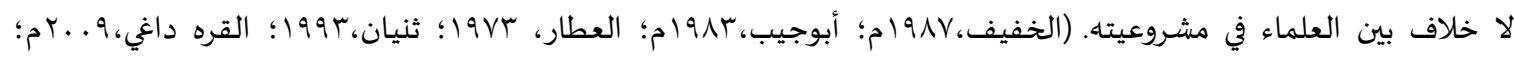

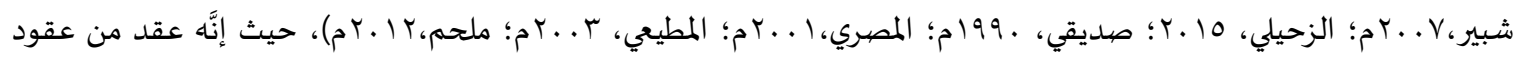

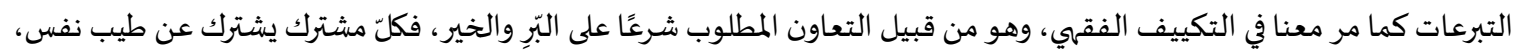

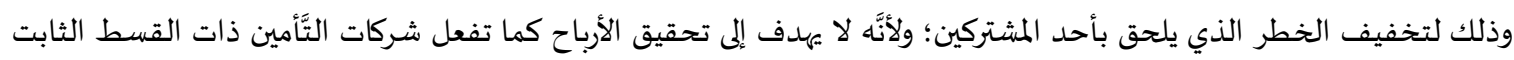

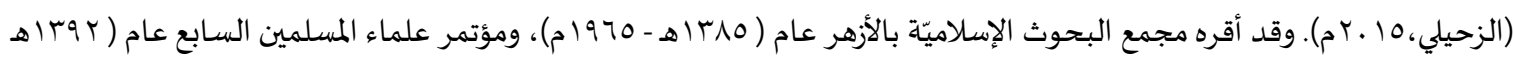

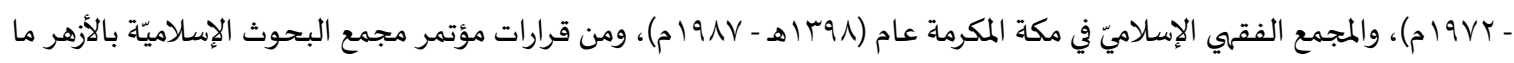

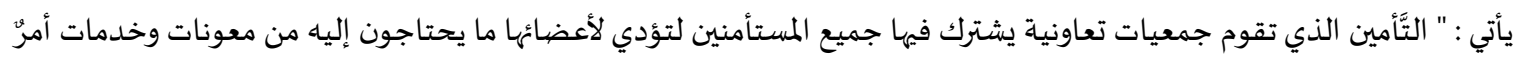

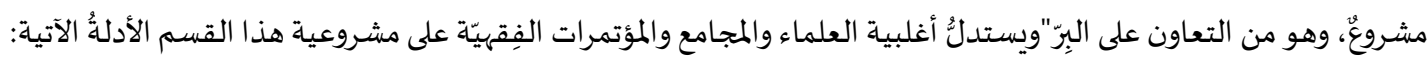

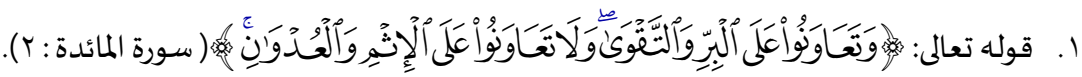

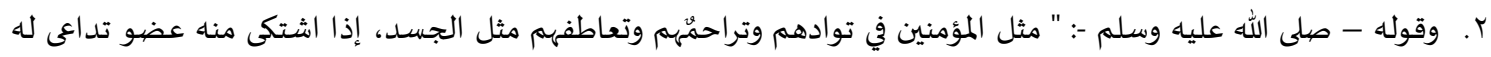

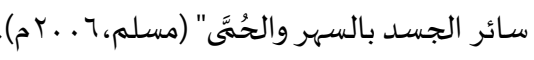

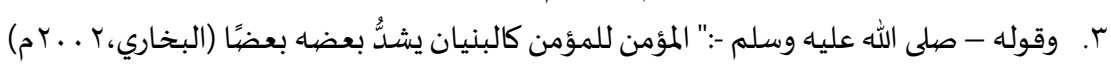

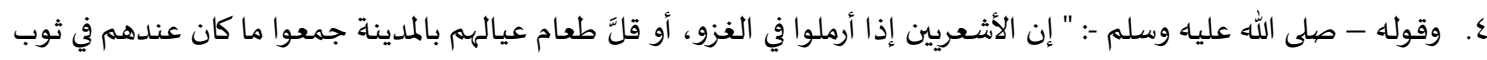

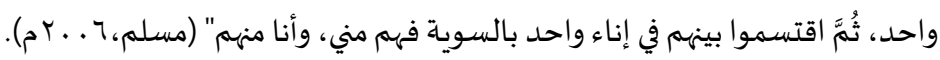

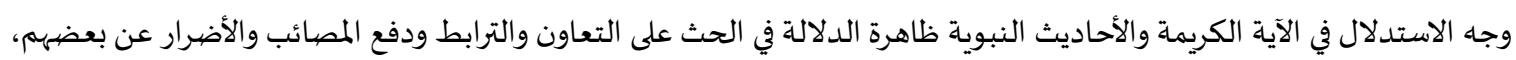

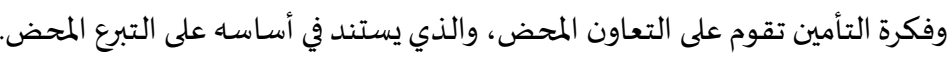

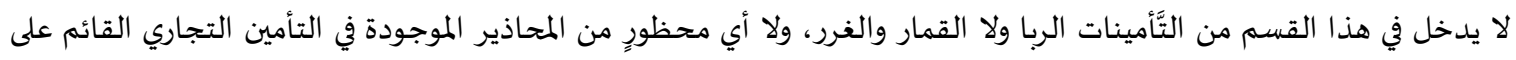

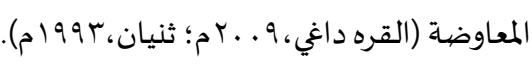


القسم الثاني: التَّأمين التَّاونيّ المتطور (الاستثماري) هو: التَّأمين الذي تقوم به شركات التَّأمين الإسلاميّ المتخصصية في مجال

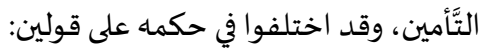

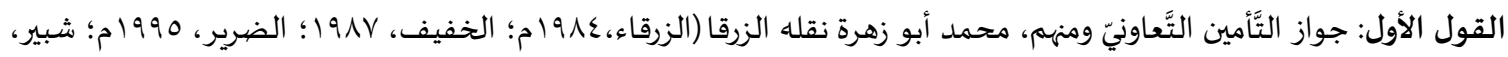

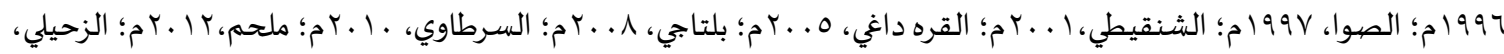

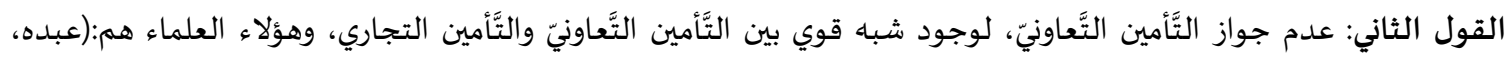

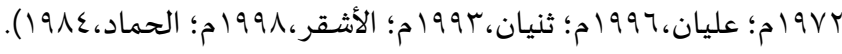

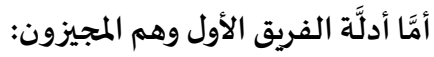

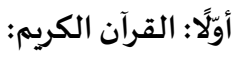

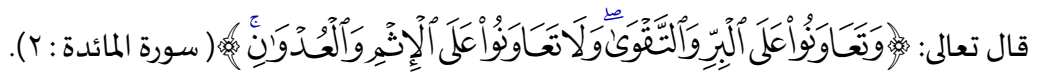

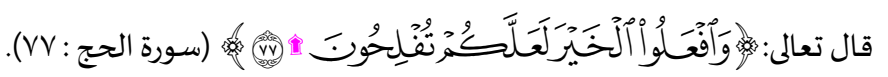

ثانيًا: السنة النبوية:

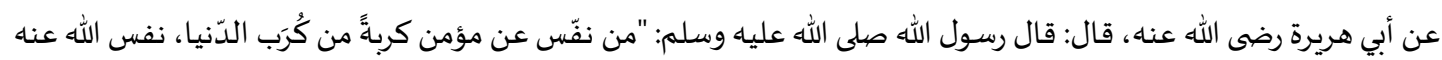

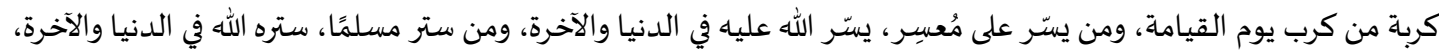

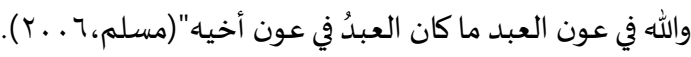

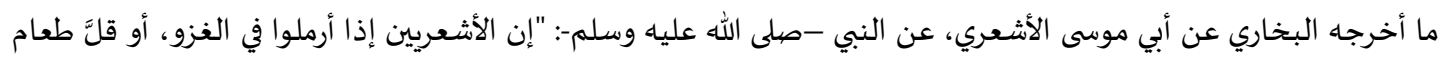

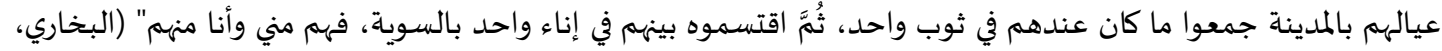

(5t...r

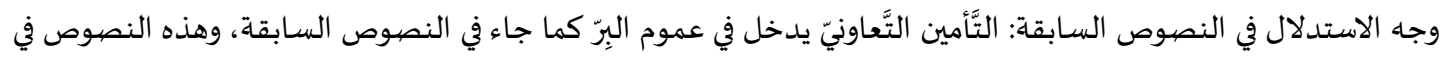

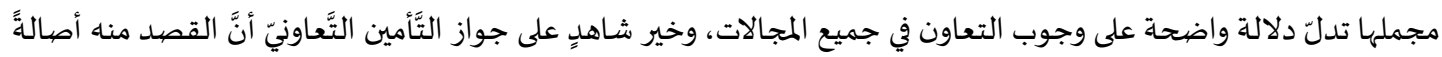
التعاونُ والترابطُو والتناصرُ.

ثالثًا: المعقول: النعان

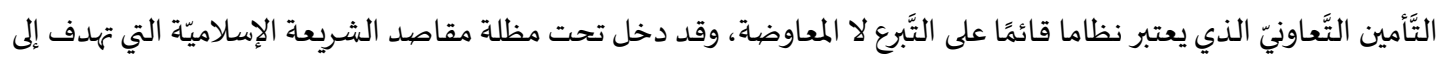

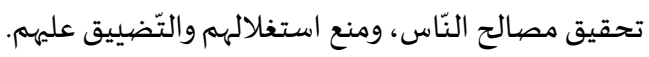

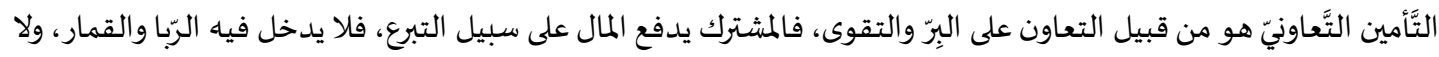

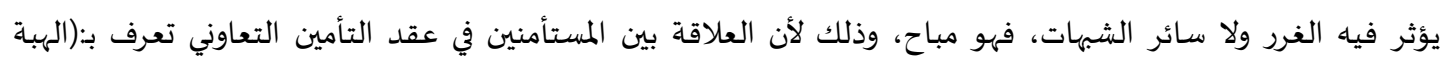

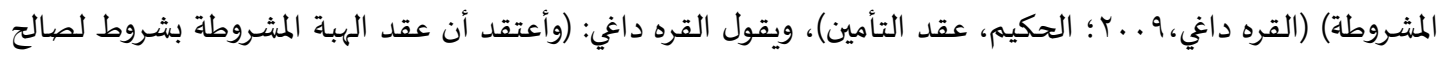

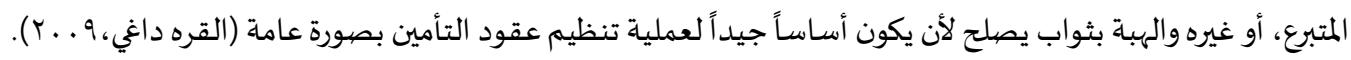

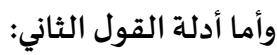

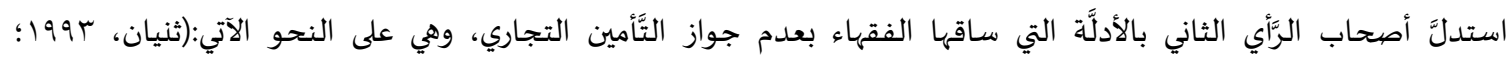

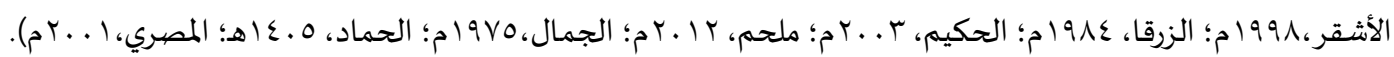

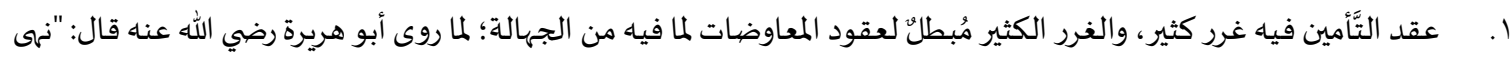
صلى الله عليه عن بيع الحصاة وبيع الغرر" (مسلم، ج . . Tم).

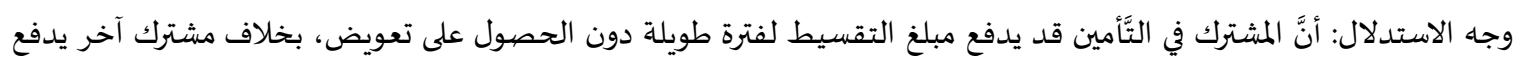

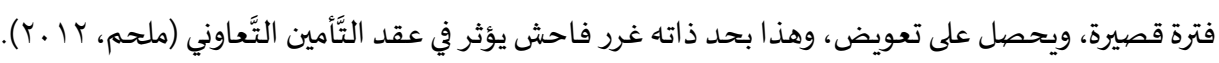

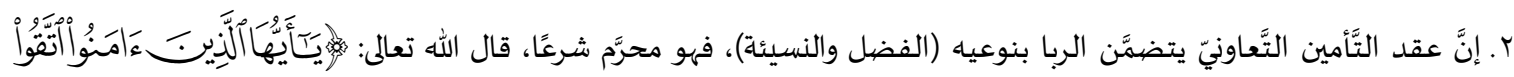

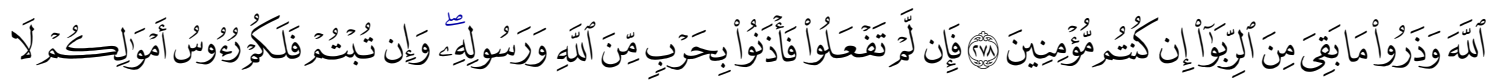

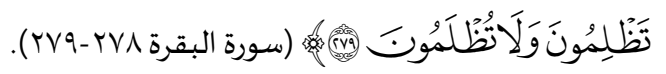




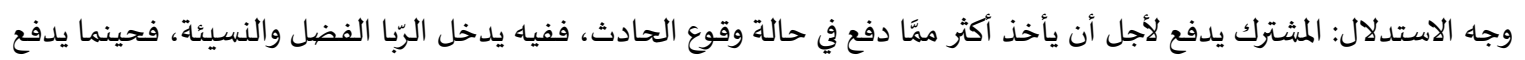

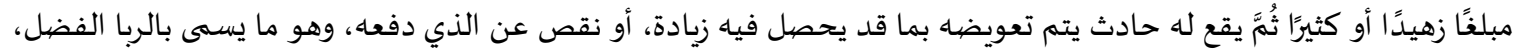

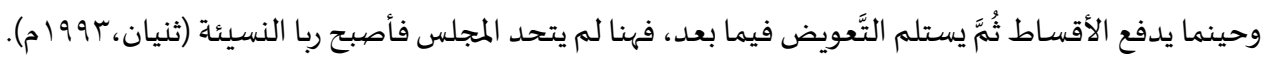

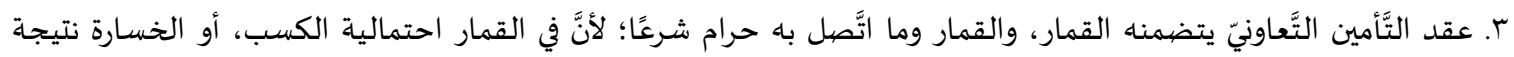

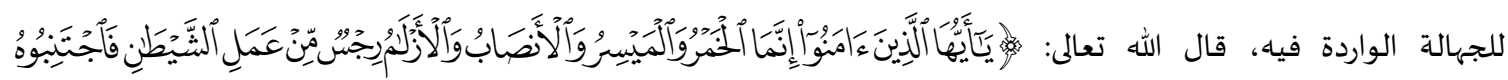

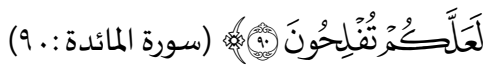

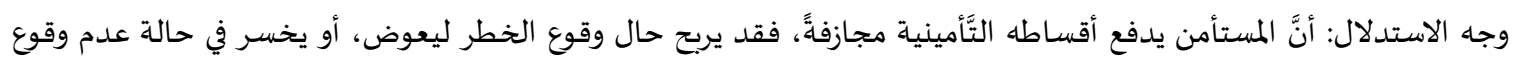

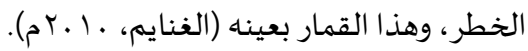

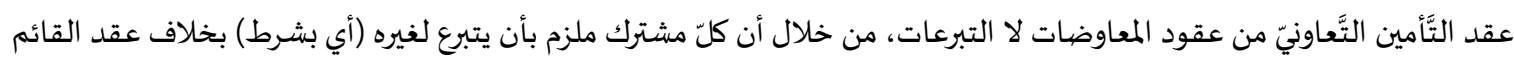

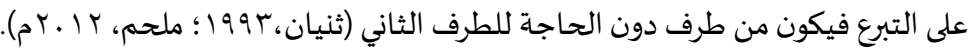

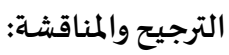

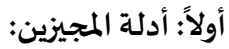
ا. إن هذه الآيات والأحاديث النبوية تحث المسلم عل التعاون والتكاتف والتكافل ولم تحدد صورة معينة أو طريقة ما للتعاون وإنما

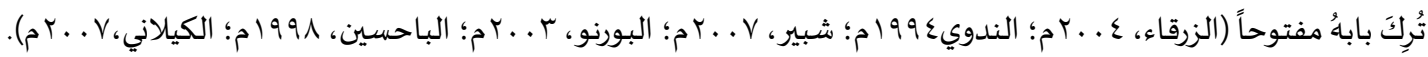

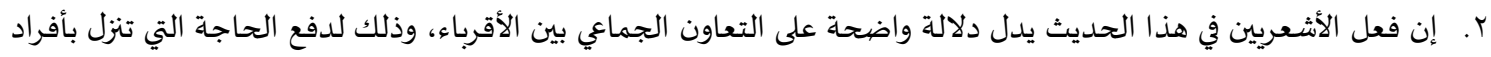

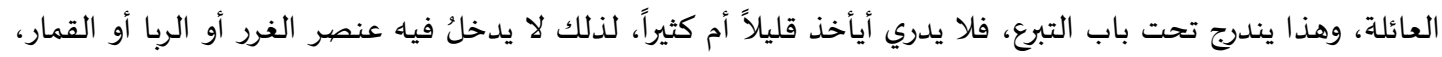

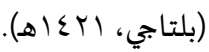

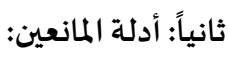

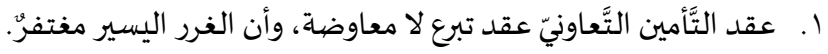

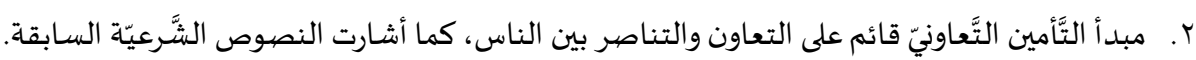

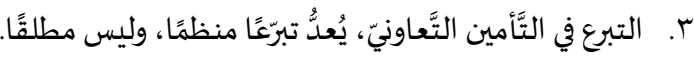

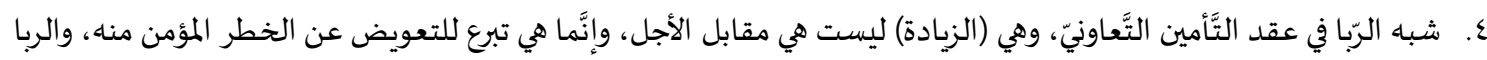

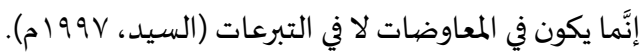
0. أن القمار محرم في عقود المعوضات بينما العقد هنا عقد تبرع لا قمار فيه.

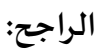

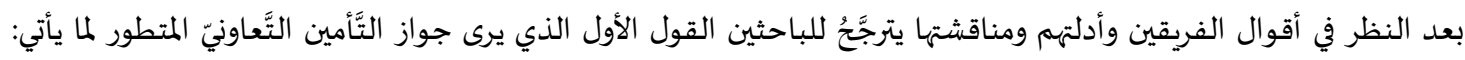

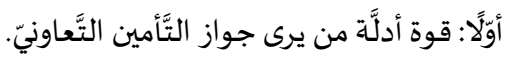

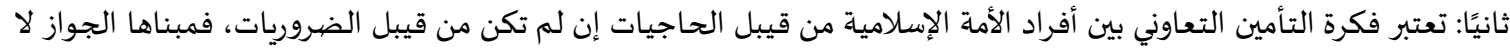

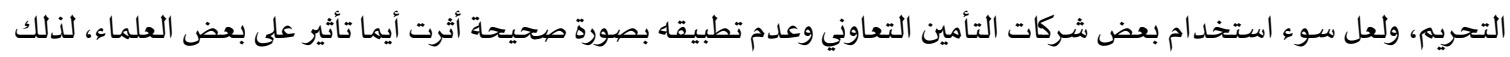

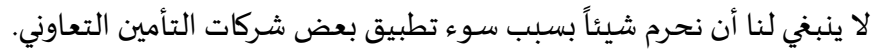

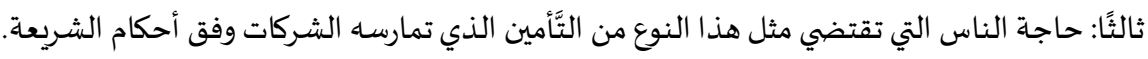

المبحث الثالث: تطبيقات عقد التَّأمين التَّعاونيّ على البنك الإسلامي الأردني وشركة التَّأمين الإسلاميّة

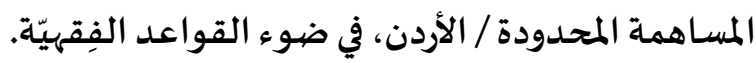

المطلب الأول: التَّامين على المركبات

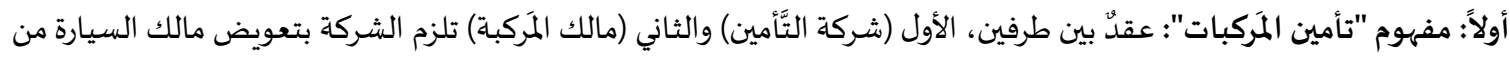

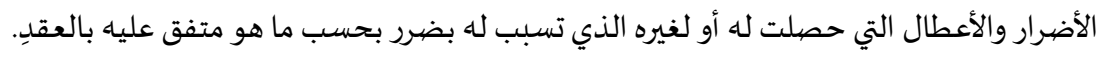

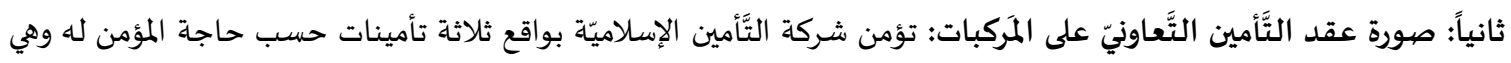

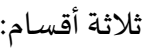


القسم الأول: التَّمين التكاملي

وهو تأمينّ ضيدّ الخسائر والأضرار التي تلحق بالعجلة الآلية أو تنشأ عنها أو لها علاقة باستعمالها عدا مخاطر المسؤولية المدنية

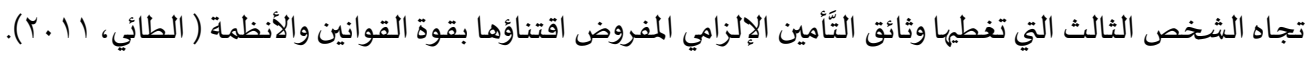

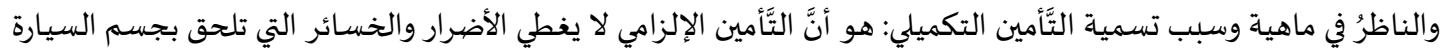

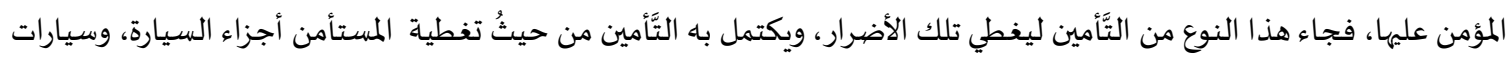

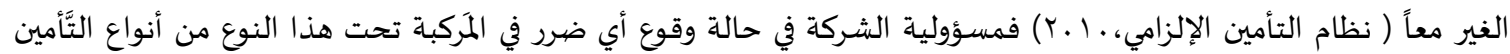

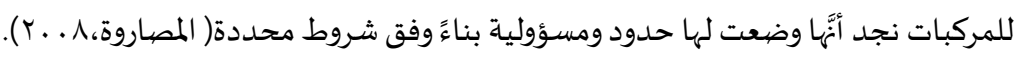

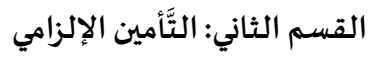

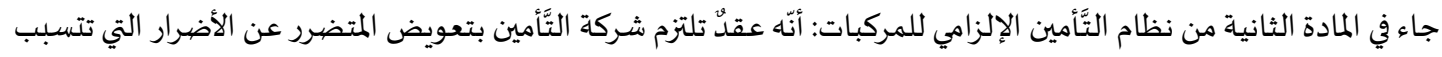

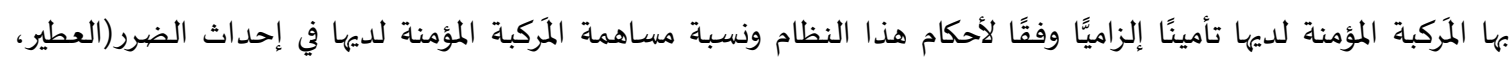

(3) 1990

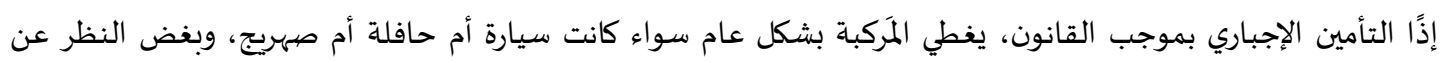

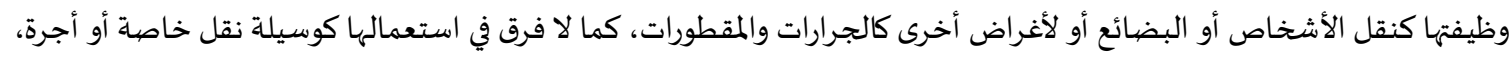

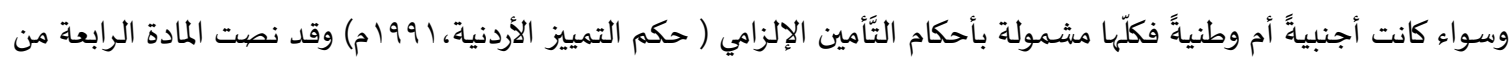

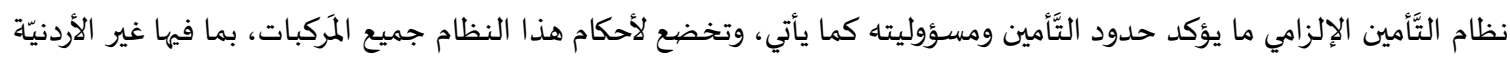

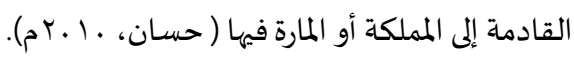

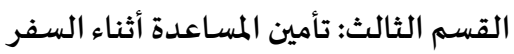

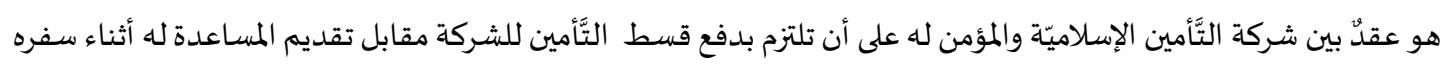
في المَركبة المحددة.

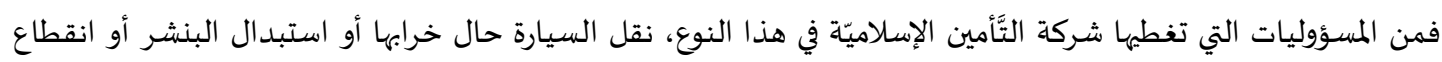

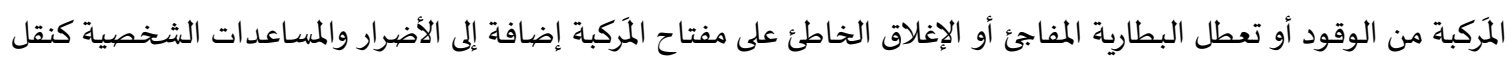

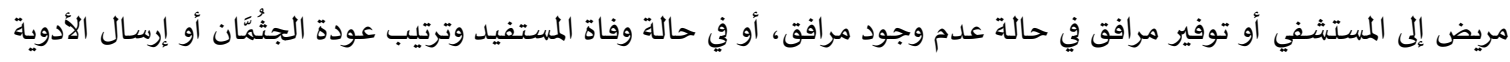

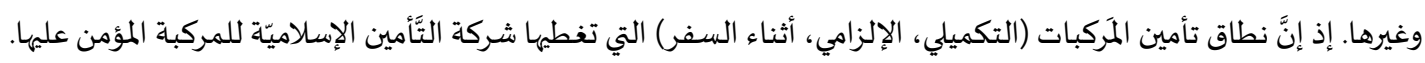

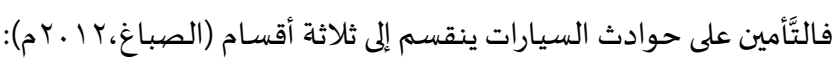

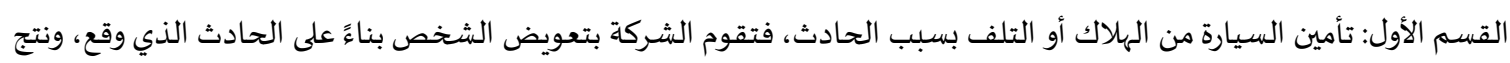
عنه الضرر، بمبلغ محدد من قبل وثيقة التَّامين (الشركة).

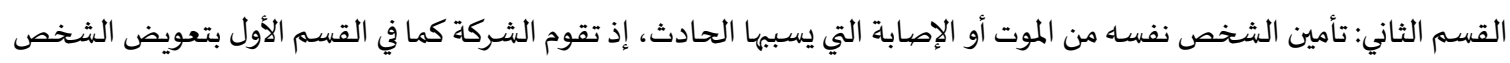

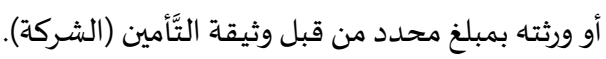

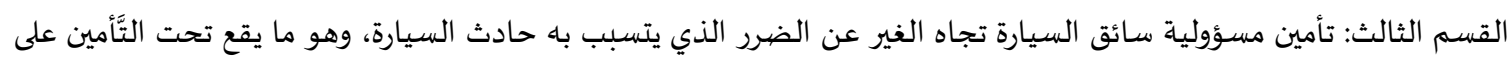

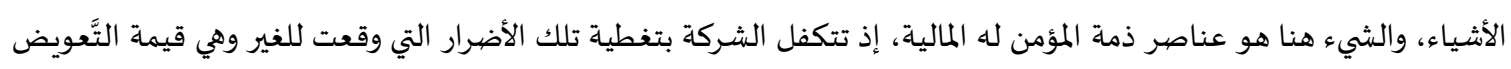
الذي يلتزم به المؤمن له تجاه المضرور.

ثالثاً: أثر القواعد الفِفهيَّة في التأصيل الفقهي لعقد التَّأمين التَّعاونيّ على المَركبات

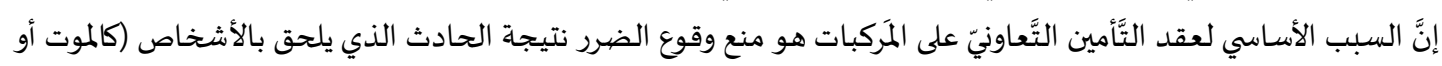

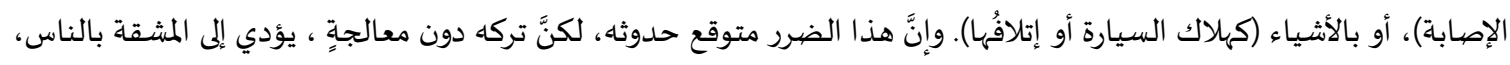

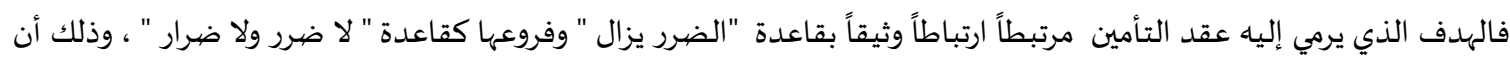

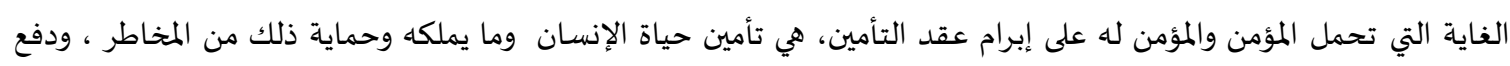

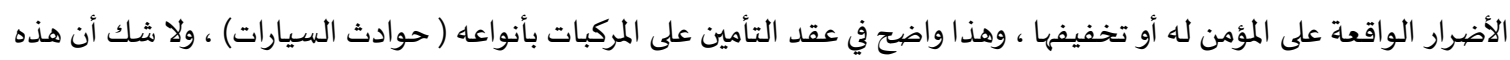

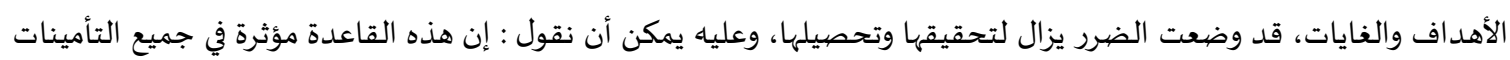

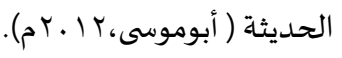


المطلب الثاني: التَّأمين ضهدّ أخطار الحريق

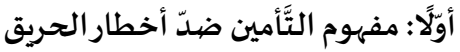

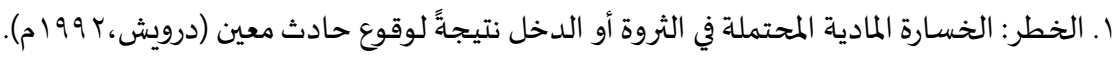
r. الحريق: "هو الاشتعال الحقيقي الظاهر الذي ينتج عن حادث مفاجئ وعارض، بشرط أن أن يكون الشيء المحترق مادة لا يتطلب الأمر

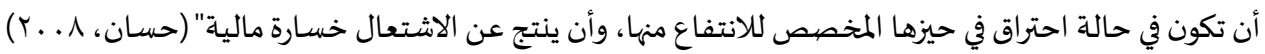
r. معنى التَّامين من أخطار الحريق مركبًا.

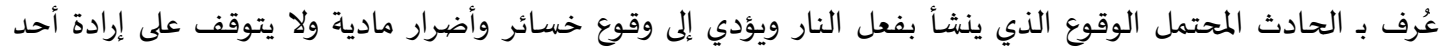

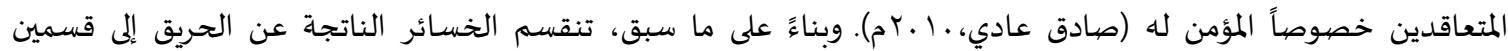

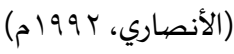
الأول: خسائر مباشرة: تكون نتيجة فعلية ومباشرة لخطر الحريق وتؤدي إلى نقص في قيمة الأصل. الثاني: خسائر غير مباشرة: هي الخسائر التي تلحق بالأصل (التكميلية).

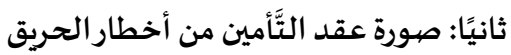
سبق أن تحدثنا حول أحقية الشركة في وضع أسس وقواعد معينة لتغطية الأضرار، وبعد النظر في عقد التَّأمين التَّعاونيّ ضدّ التّا

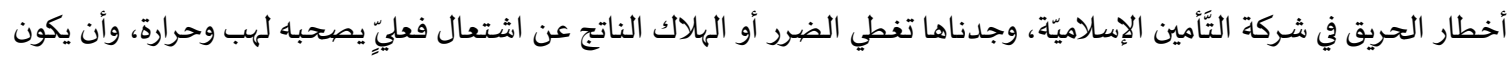

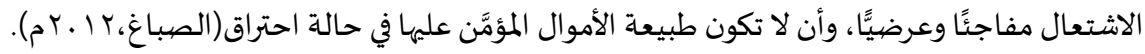

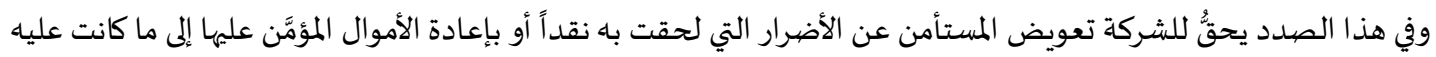

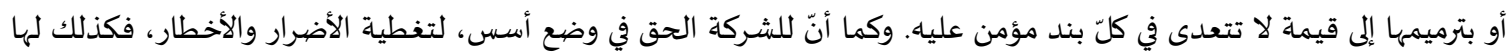

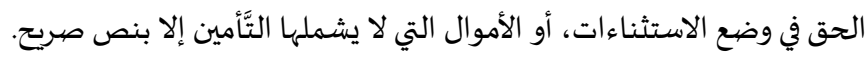

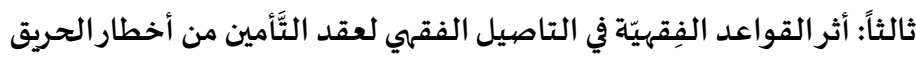

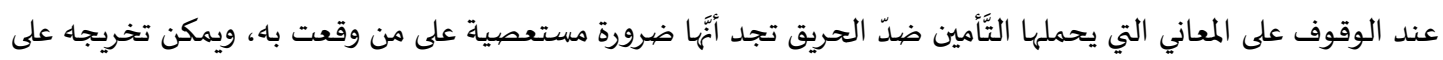

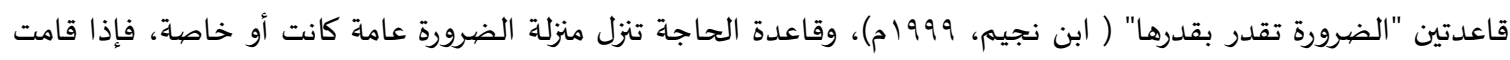

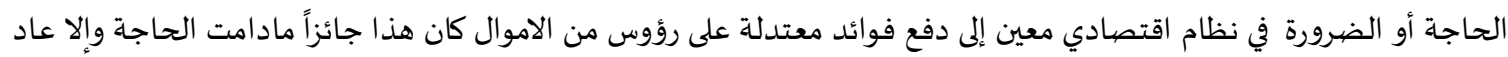

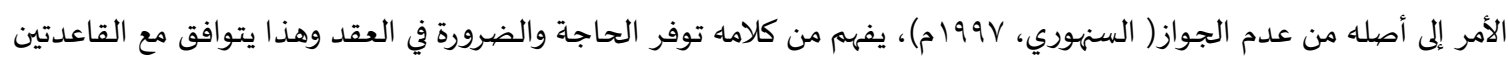

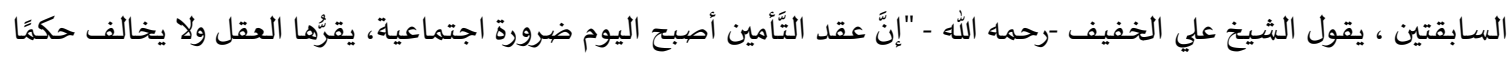

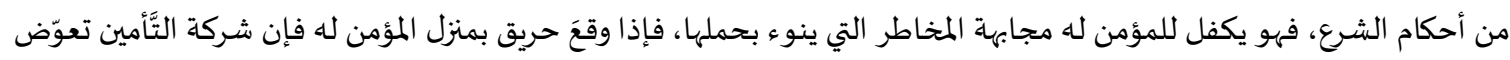

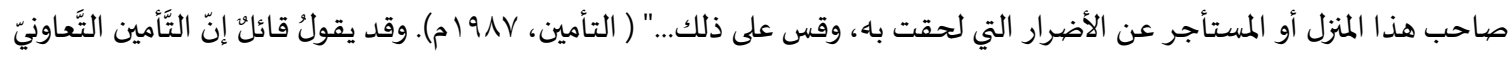

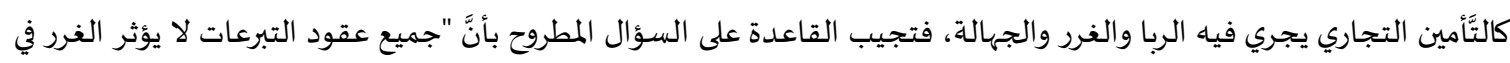

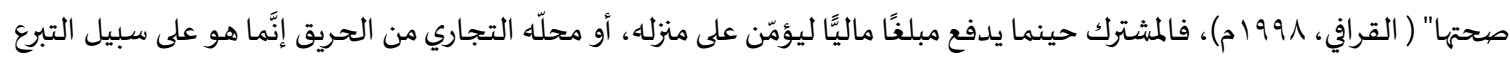

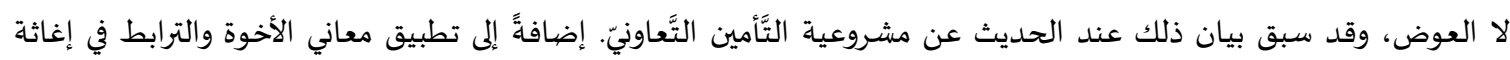

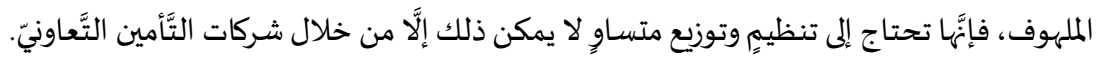

$$
\begin{aligned}
& \text { المطلب الثالث: نفقات العلاج الطبي التَّعاونيّ } \\
& \text { أوَّلًا: معنى التَّأمين الطبّي }
\end{aligned}
$$

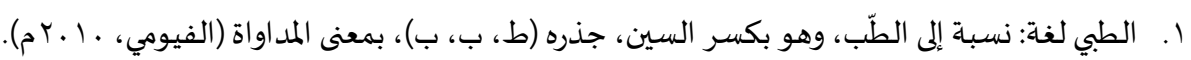

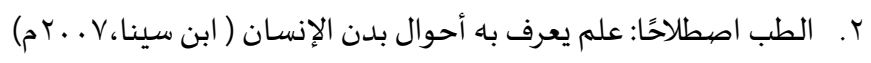

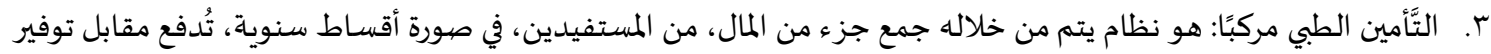

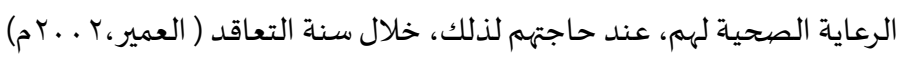

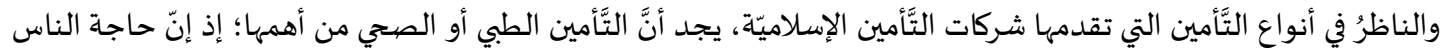

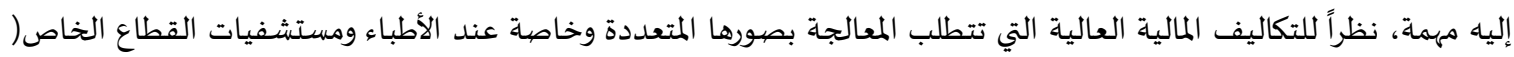

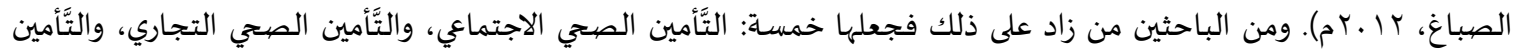

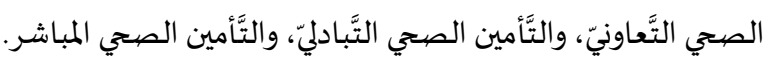


ثانيًا: صورة عقد التَّأمين الطبي

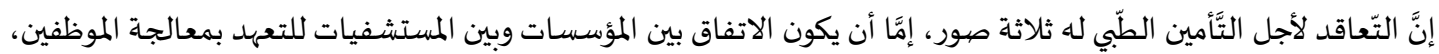

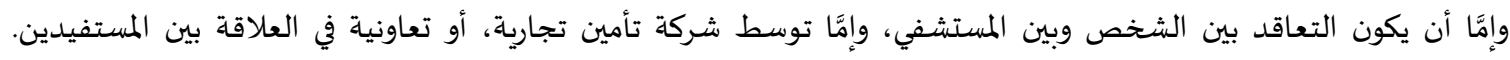

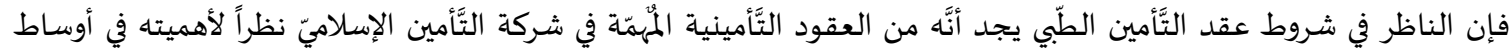

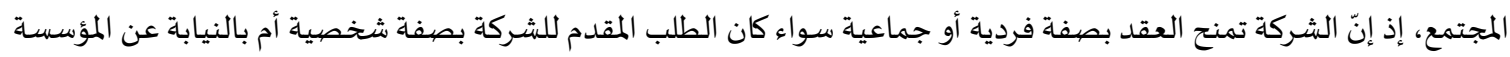

للعاملين فيها.

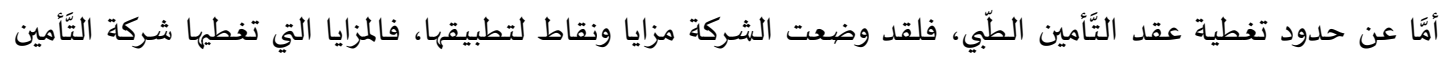

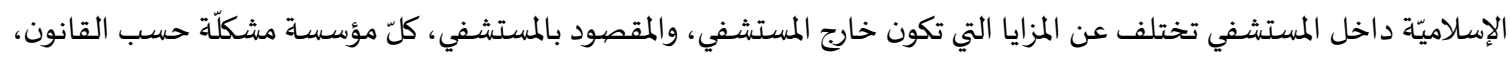

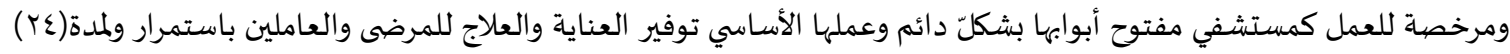

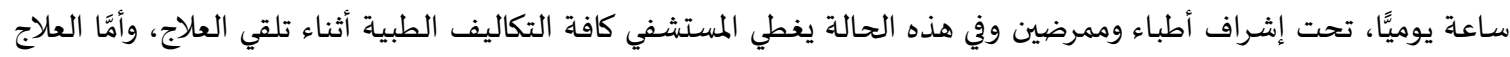

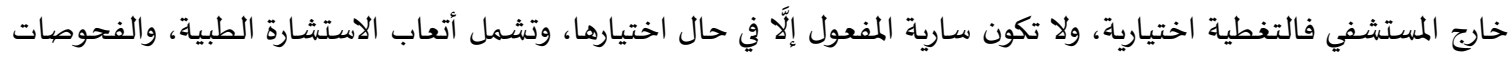

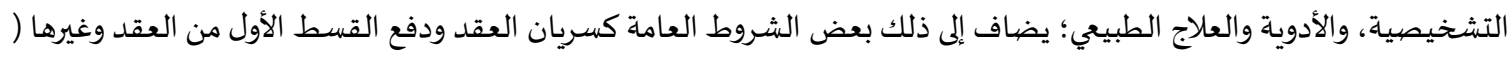

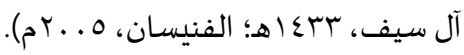

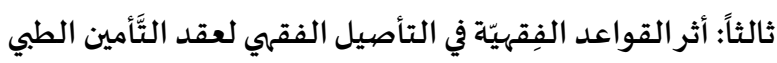

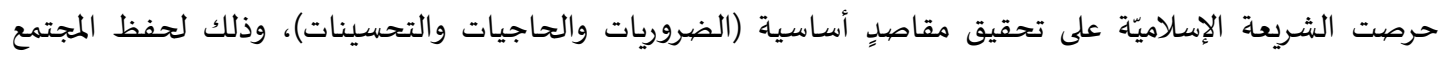

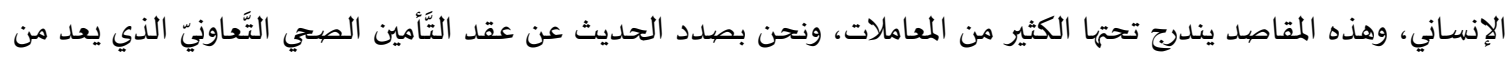

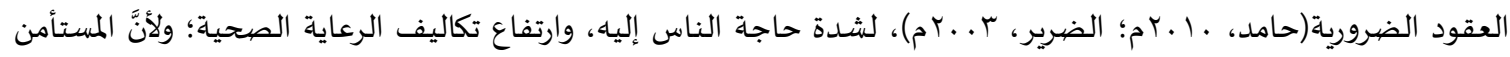

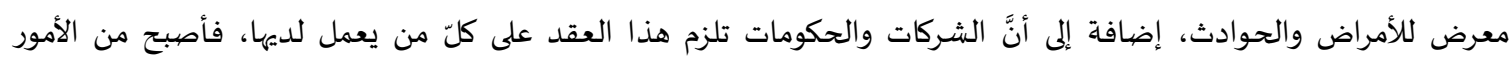
الاضطرارية.

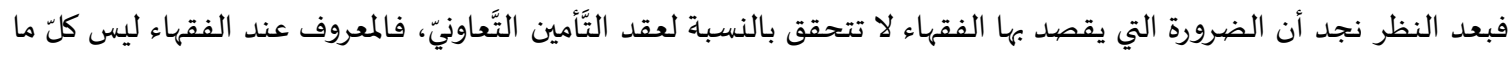

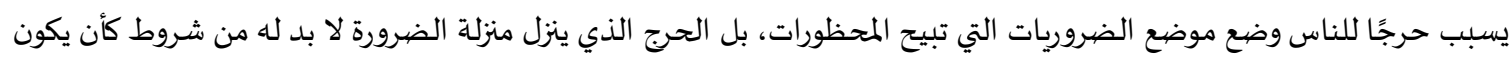
شديداً عامًا، ويؤديّي إلى الهلاك والمشقاسة العظيمة.

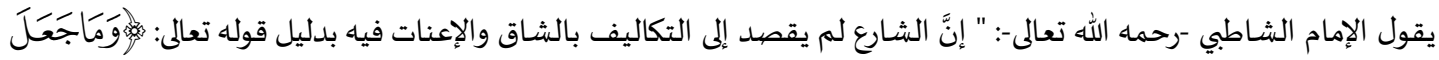

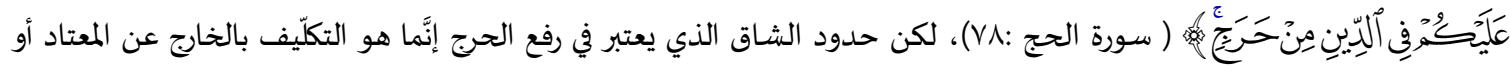

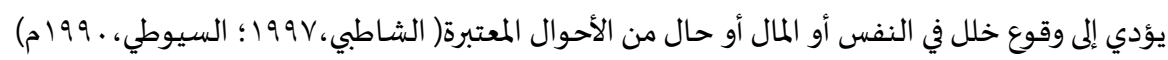

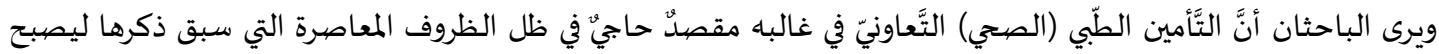

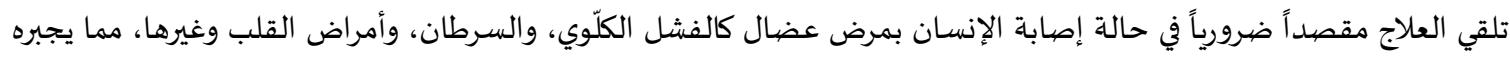

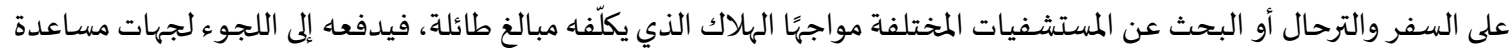

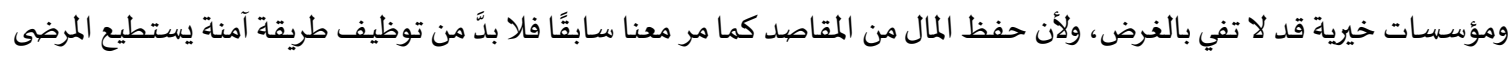

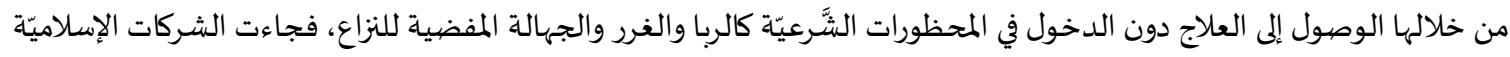

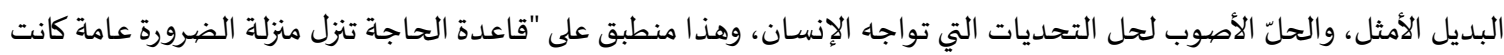

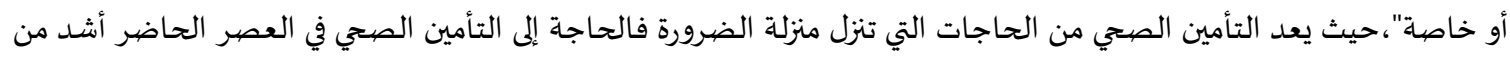

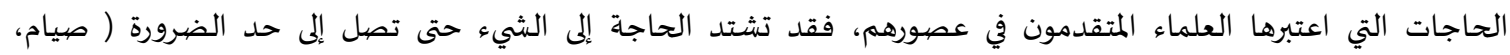

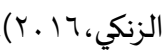
ويمكن تخريجه على قاعدة " تصرف الإمام على الرعية منوط بالمصلحة" فلأجل التكافل الاجتماعي تلزم الدولة أفرادها

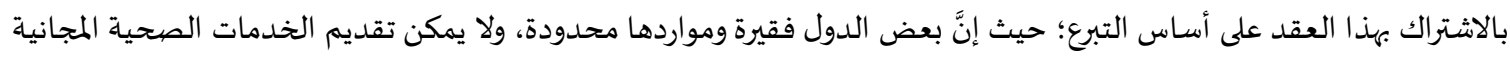

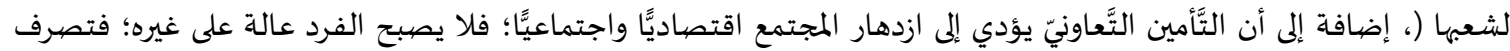

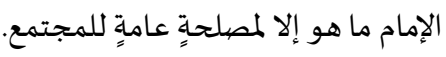


المطلب الر ابع: التَّأمين على الحياة

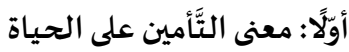

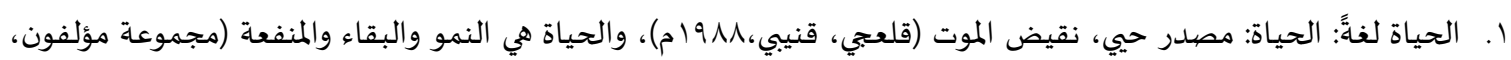

. (3.)

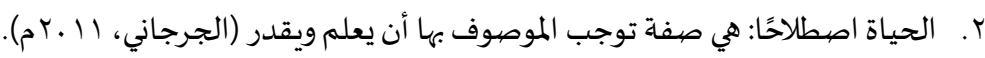

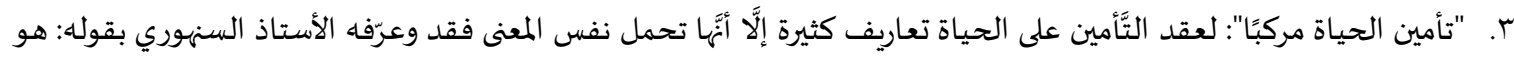

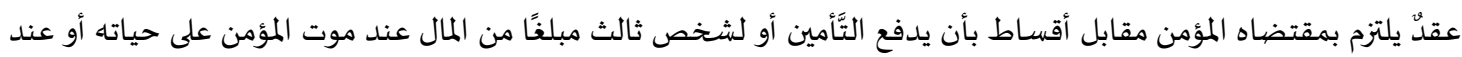

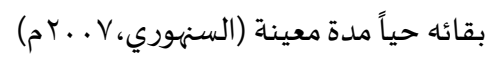

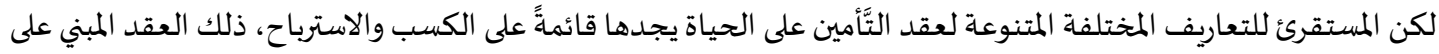

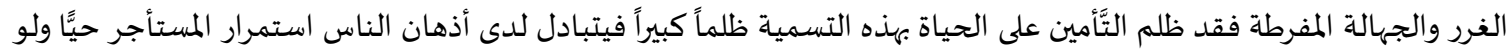

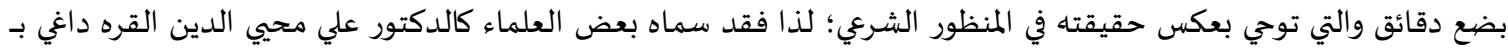

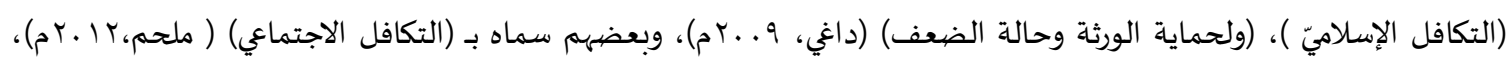
وأطلق علياء في بعض الدول بـ (الضمان الاجتماعي) التابع للدولة أو ضمن شركات التَّامين الإسلاميّ التي من غاياتهم ترميم المخاطر في

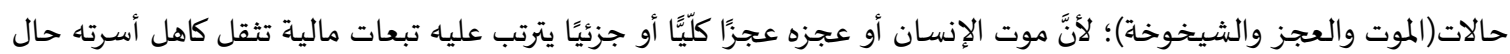

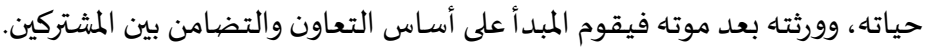

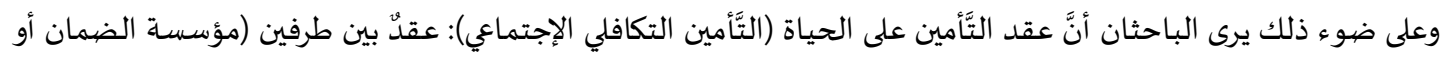

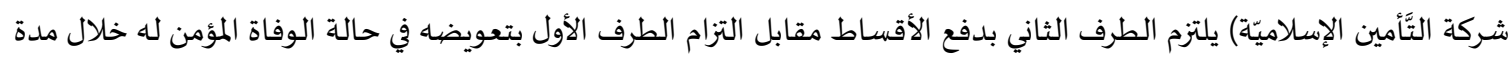
التَّأمين أو عجزه

ثانيًا: صهورة عقد التَّأمين على الحيناة

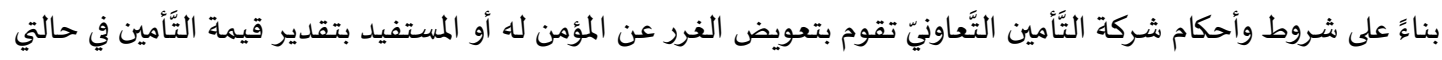

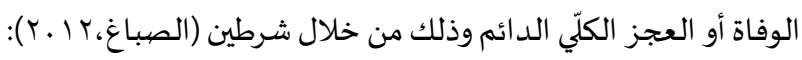
ا. أ. وقوع أحد الحالتين (الوفاة أو العجز الكلّي) خلال فترة التَّأمين.

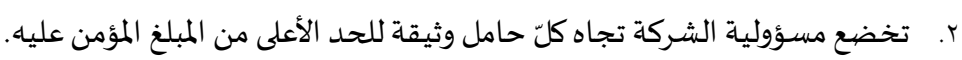

ثالثاً: أثر القواعد الفِقهيّة في التأصيل الفقهي لعقد التَّأمين على الحياة

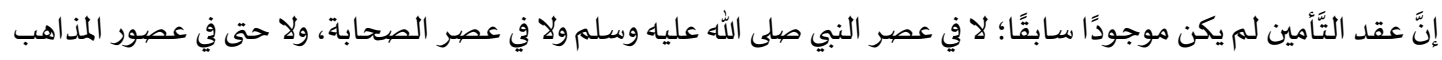

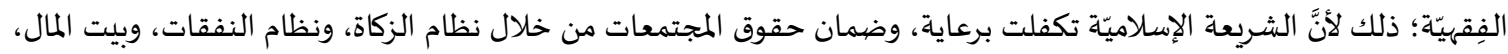

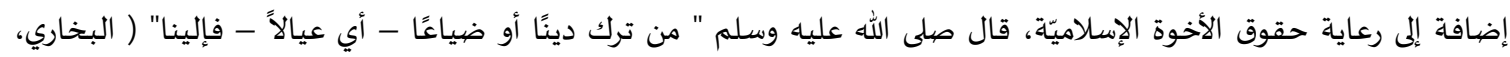

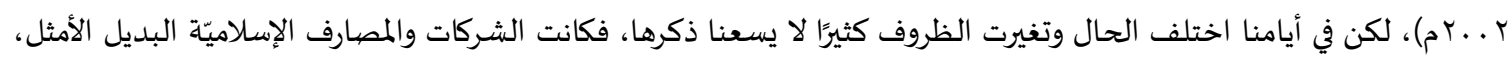

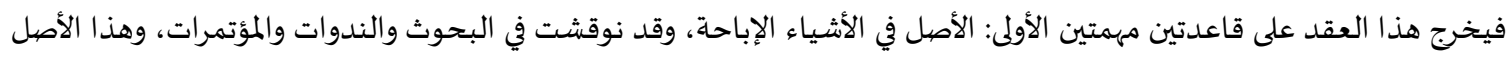

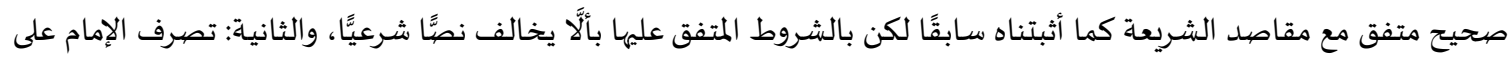

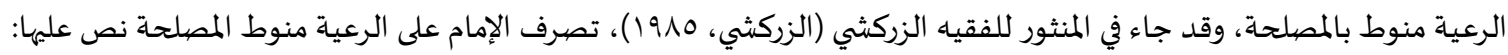

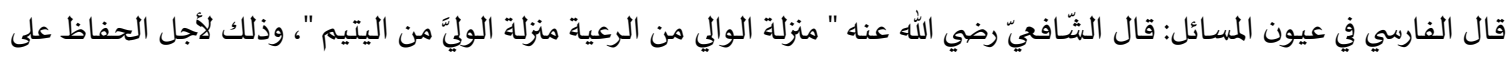

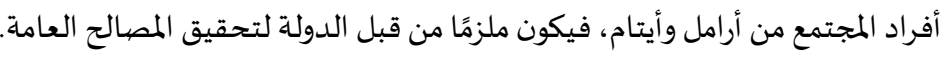

$$
\text { ألمًَا: معلب الخامس التَّمين التَّأمين على الودائع }
$$

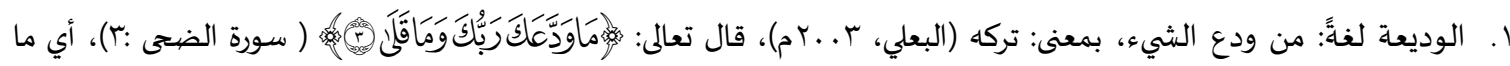

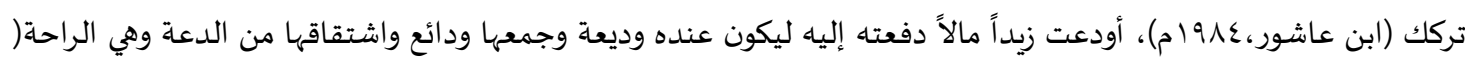

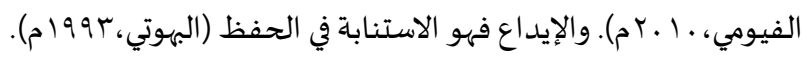

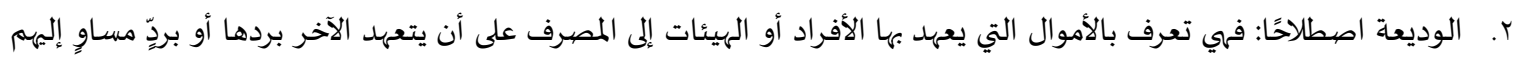

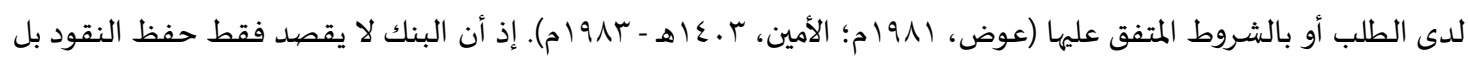


يتعدى الأمر إلى الاستثمار والفائدة، إضافةً إلى اختلافها عن الوديعة من حيث التكييف الفقهي لها فها لهائ توكيلٌ أو استنابة في

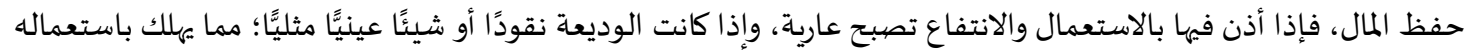

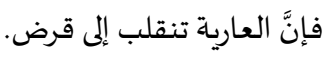

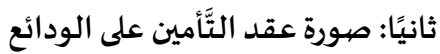
قبل الحديث عن حدود التغطية المُتعلّقة بالتَّأمين على الودائع لا بد أن نميز الودائع في المصهارف الإسلاميّة، حيثُ أنّّ الودائع المصرفية في المصارف الإسلامية على نوعين:

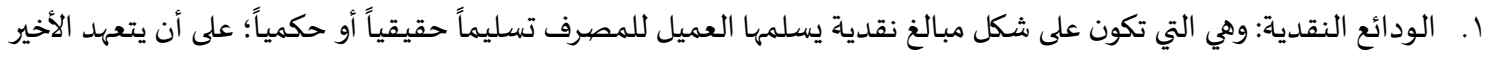

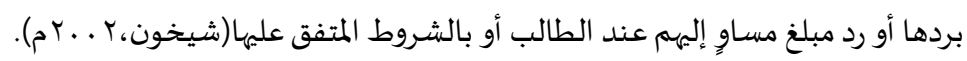

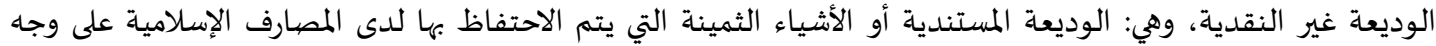

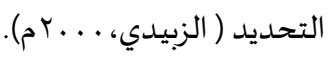

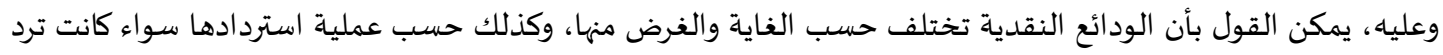

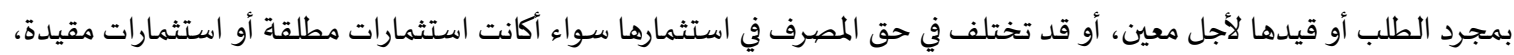

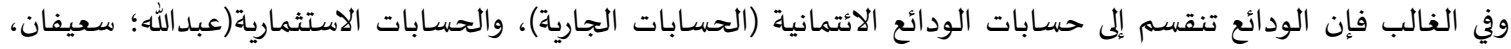

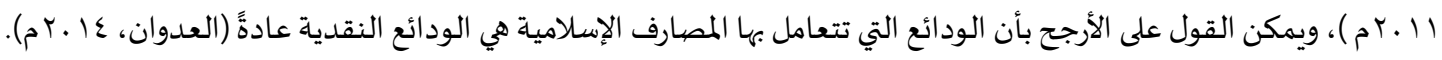

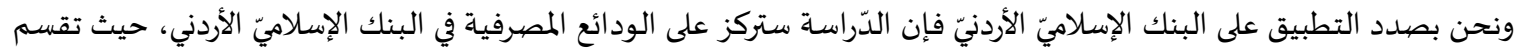
الودائع المصرفية فياء إلى قسمين: القسم الأول: الودائع الائتمانية (الحسابات الجارية والحسابان الحابت تحت الطلب):

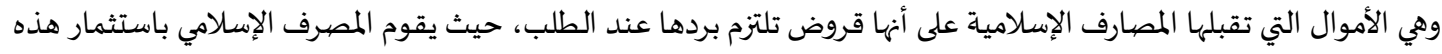

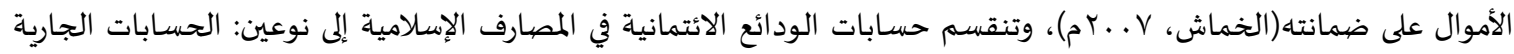

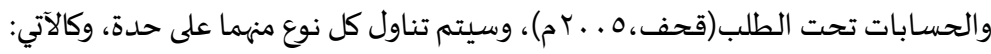

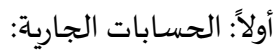

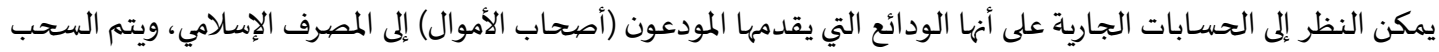

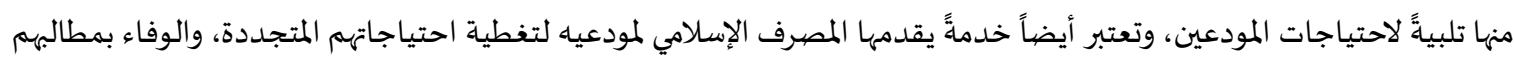
المالية والمصرفية المتطورة والمستمرة(الجندي،)، إضافةً إلى صونها والمحافظة عليهات المانيا.

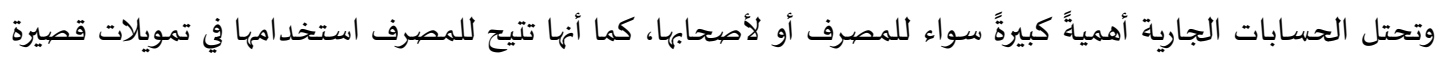

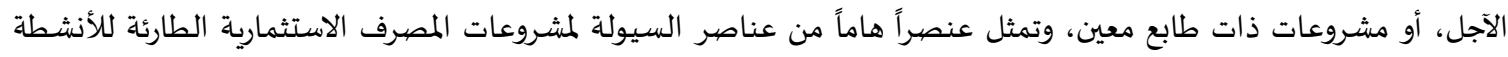

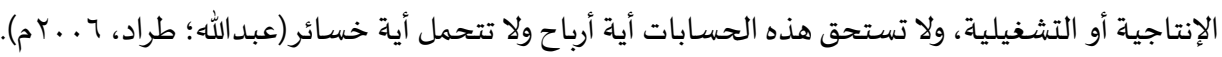

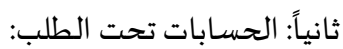

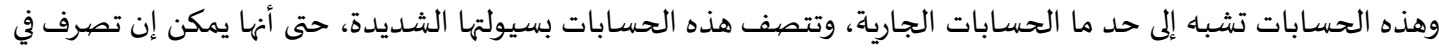

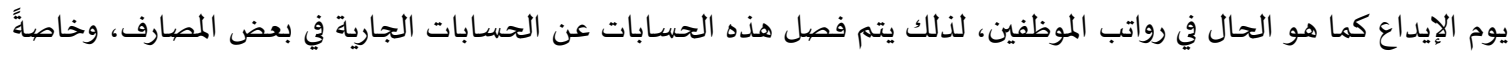

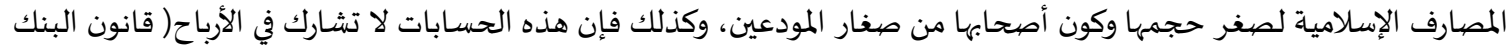

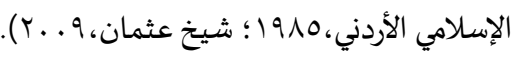

القسم الثاني: حسابات الاستثمار (الودائع الاستثمارية):

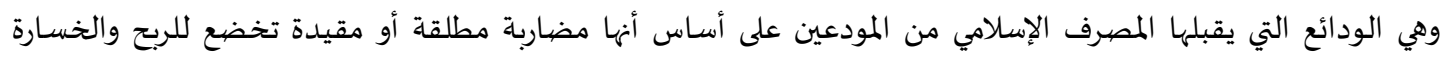

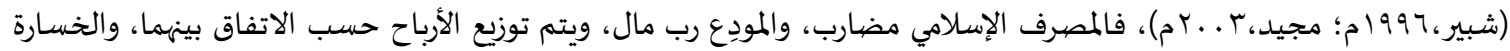

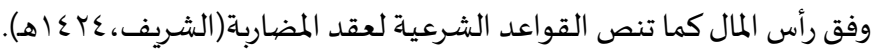

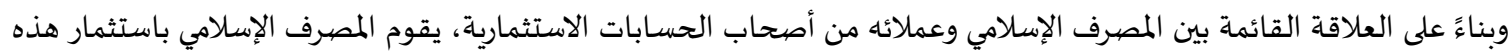

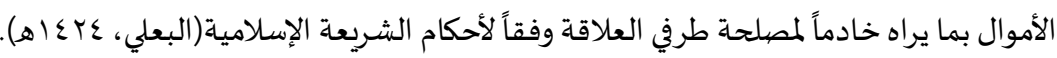

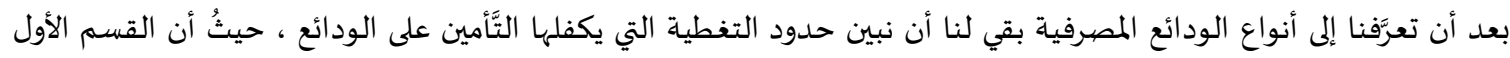

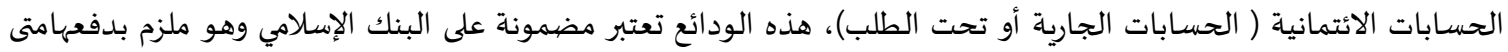


طلبها أصحابها وهذا الأمر راجع إلى تكييف هذه الودائع على أهها قرض فمجرد إيداع العملاء أموالهم لدى البنك كانوا مقرضين له،

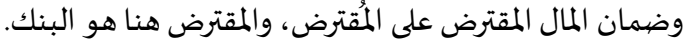

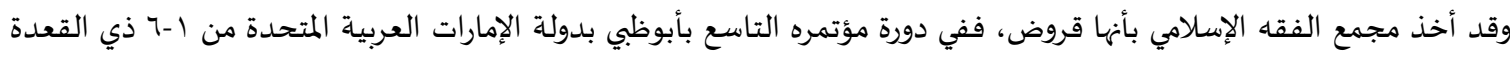

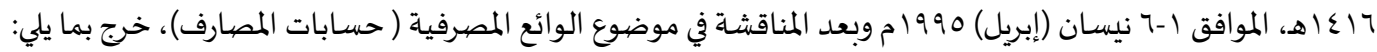

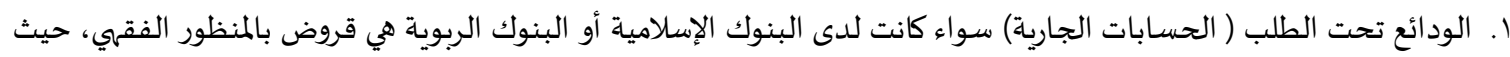

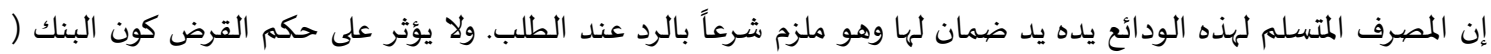

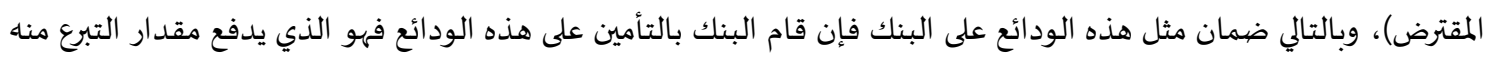
للمؤسسة القائمة على ضيمان الودائع.

ז. الودائع الاستثمارية : يقوم البنك بدور الوكيل عن أصحاب الأموال في إدارتها واستثمارها بالوجه الذي يران الداه مناسباً ويستحق على هذا

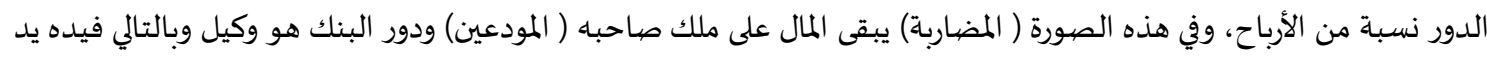

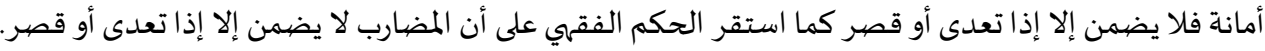

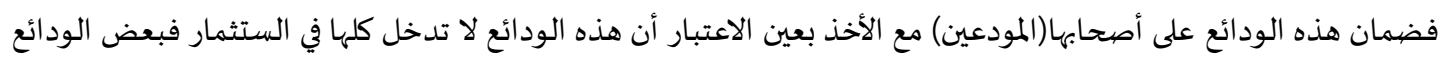

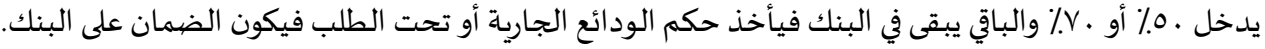

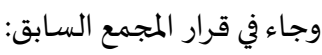

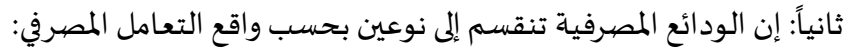

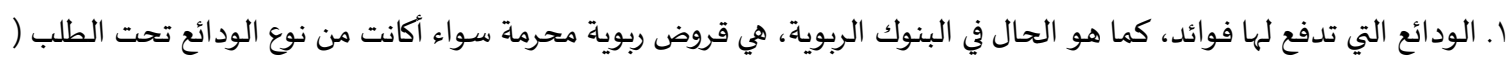

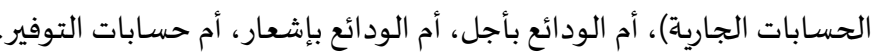

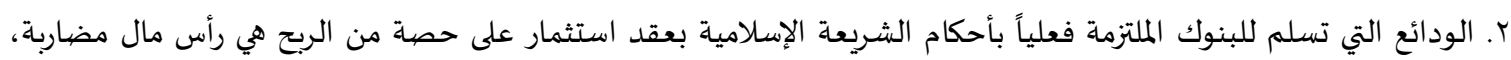

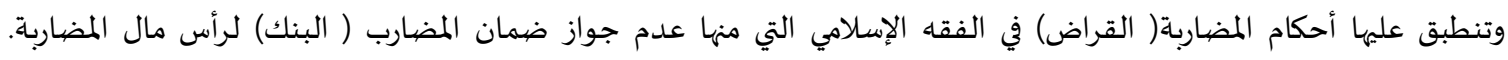

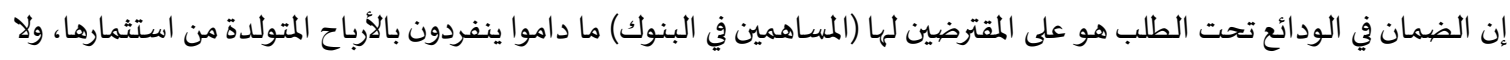

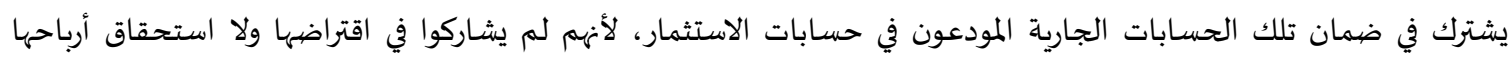

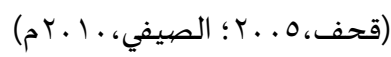

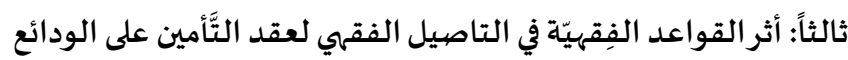

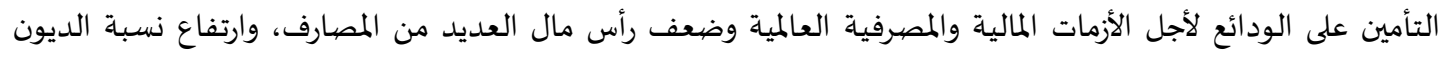

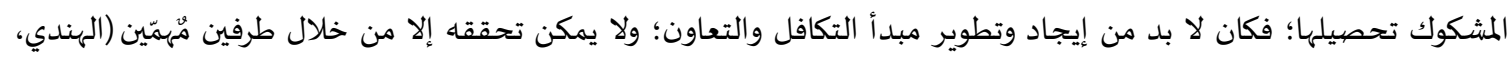

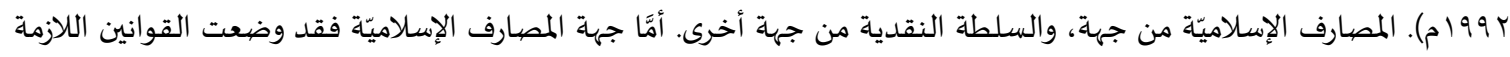

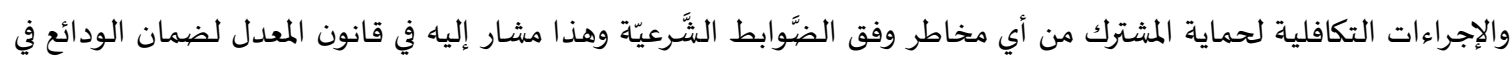

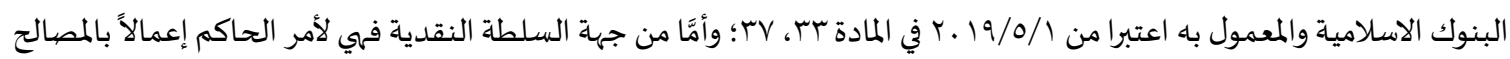

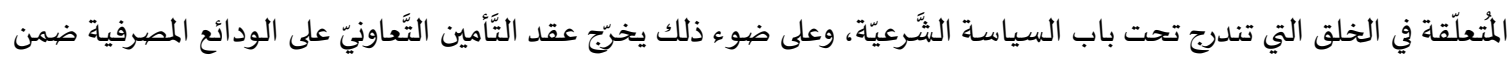

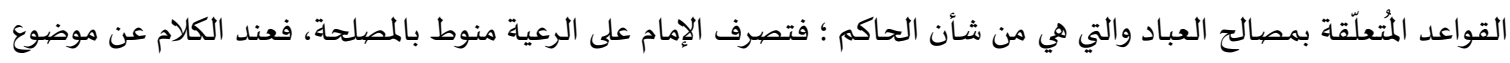

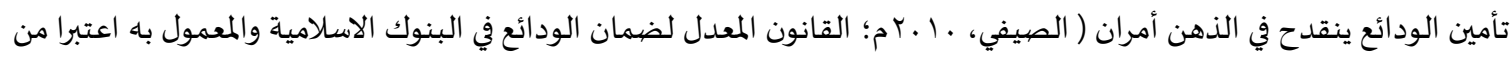

الأول : ضمان الودائع عن طريق مؤسسات حكومية أو شباه حكومية (مؤسسات ضيمان الودائع).

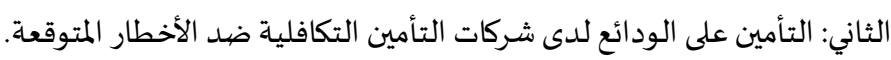

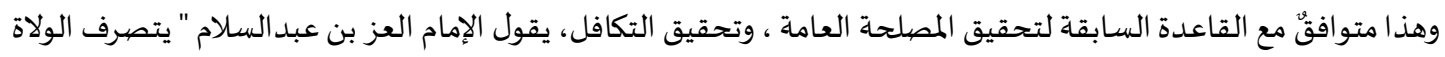

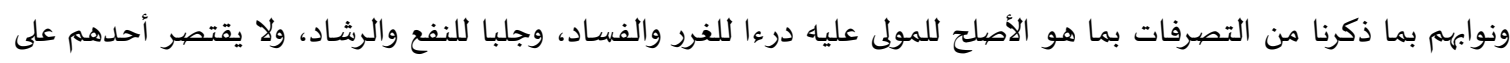

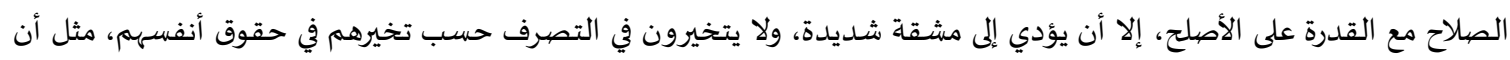

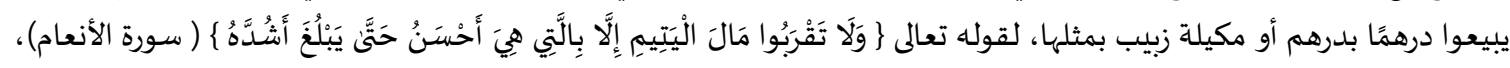

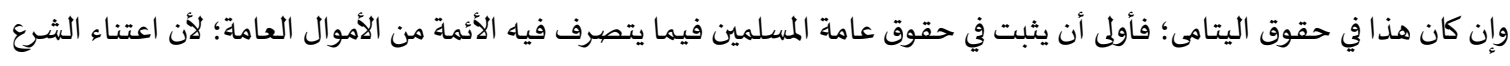

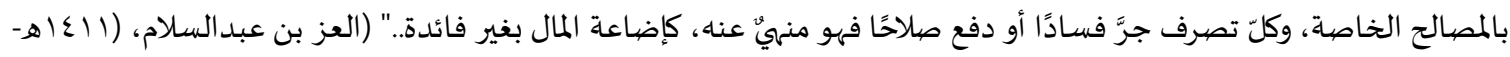


وبالتالي فالتأمين على الودائع هو (دين) إما أن يكيف على أساس النهد (والالتزام بالتبرع، أو على أساس الهبة بثواب وهذه أصهول

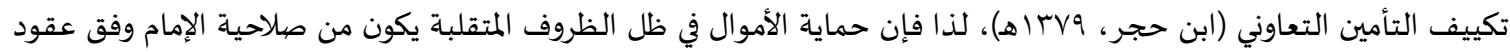
التَّأمين التَّعاونيّة.

$$
\begin{aligned}
& \text { المطلب السادس: التََّّمين التَّعاونيّ على الديون }
\end{aligned}
$$

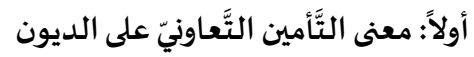

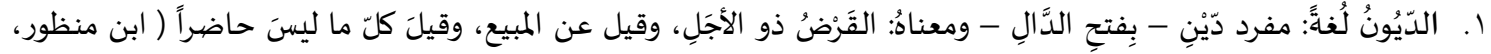

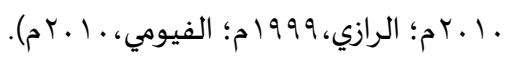

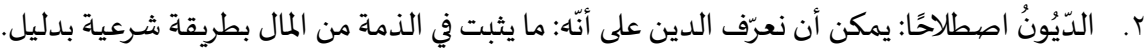

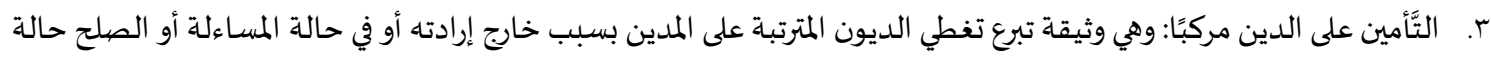

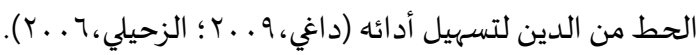

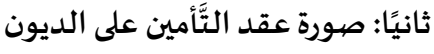

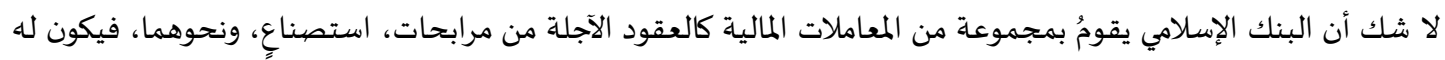

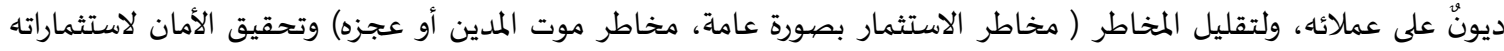

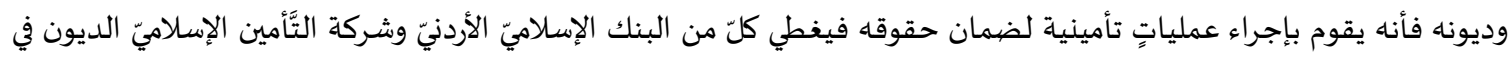

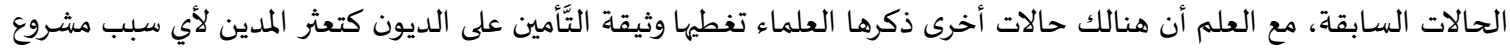

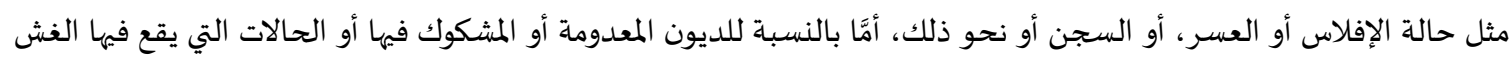

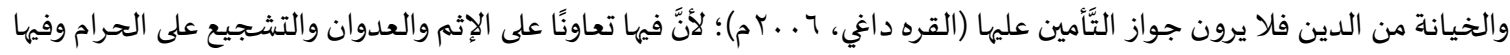

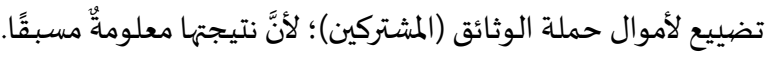

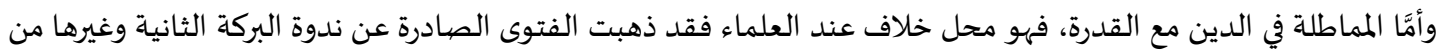

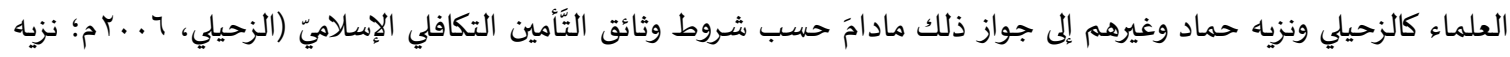

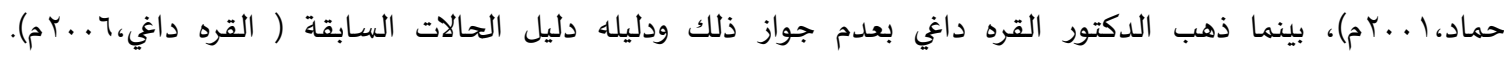

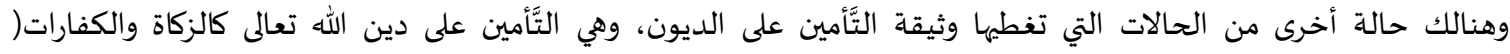

$$
\text { الصيفي، · ( - r م). }
$$

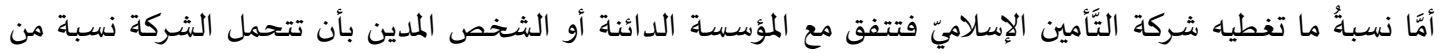

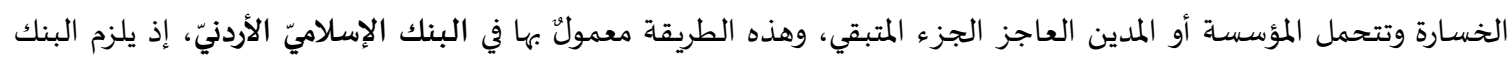

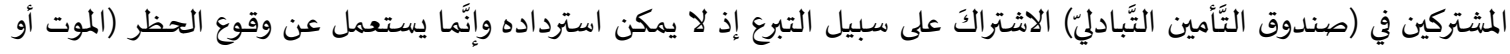

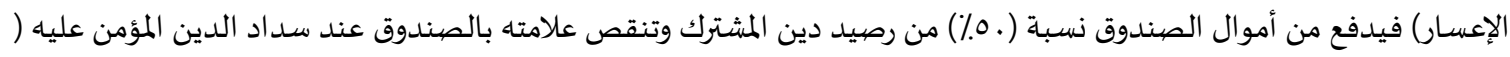

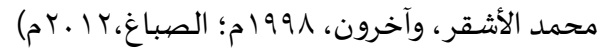

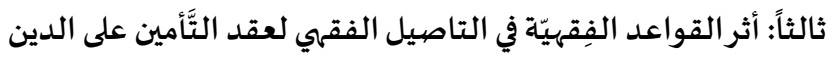

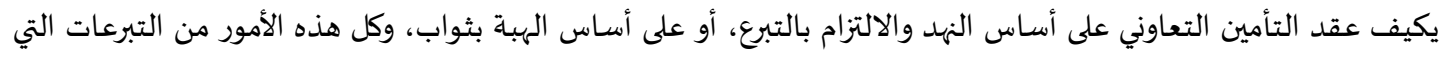

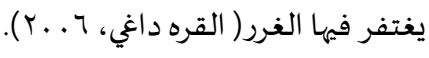

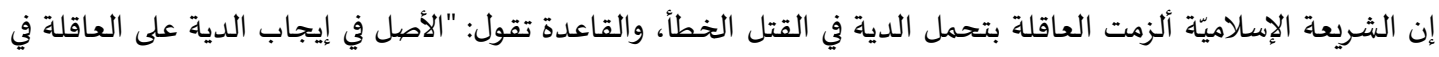

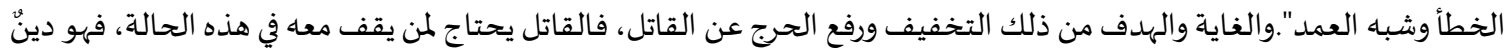

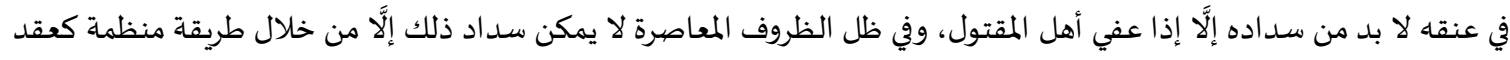

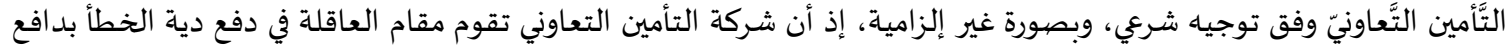

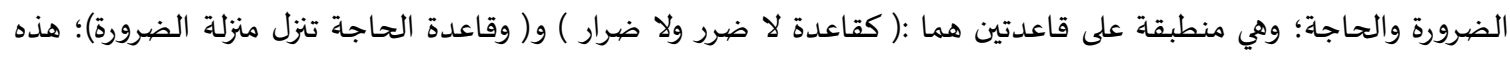

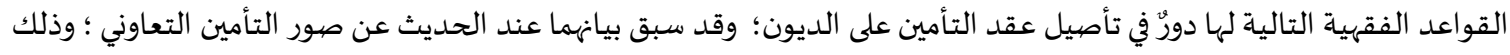
في ضوء التطورات والمستجدات، وقد بينا سابقاً حول تحمل شركة التأمين التعاونية محل التهائ العاقلة وعلاقهتها بها. 
ويقول ابن القيم الجوزية " إنَّ كلّ شرط لا يخالف حكمه، ولا يناقض كتابه وهو ما يجوز تركاه وفعله بدون الشروط، فهو لازم بالشرط " (ابن القيم الجوزية، بلو ام)، وقد قرر فقهاء الحنفية قاعدة " المواعيد بصورة التعاليق تكون لازمة"، وعليه فإنَّ التَّأمين على الديون المقرر ذكرها سابقًا تصبٌّ في مصلحة الناس حيث ترمم الكوارث المالية وتدفع المفاسد وهي وفق وفئ قاعدة العاقلة.

الخاتمة

أولاً: النتائج:

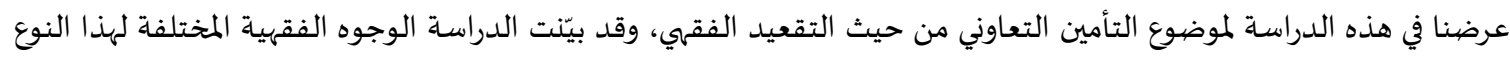
من التأمين وعرضت لجميع الآراء التي ناقشتاء. وكان هدفها محاولة إيجاد حاضنة فقهية تحوي هذا النوع من التأمين. كما حاولت

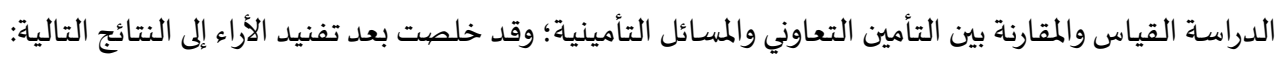
ا. إن التأمين التعاوني المتطور عقد مركب من جملة من العقود، والتي تتمثل بعقد التعاون الجماعي، والتبرع عن طريق الهباة، ووكالة بأجر، ومضاربة، وكفالة. r. ينبغي على العاملين في شركات التأمين إعمال الشريعة الإسلامية عند النظر في أحوال التأمينات.

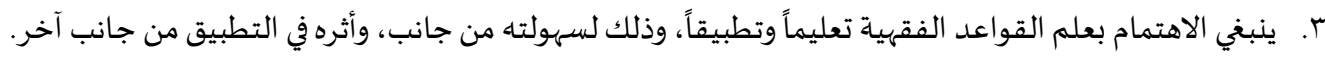

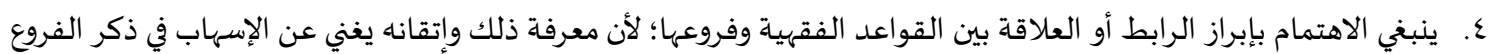

المندرجة؛ فهو بمثابة تعليم الصيد للمحتاج إليه، ولا شك أن تعليماه ذلك ليقوم باه دون حاجة إلى أحد أولى. ثانيًا: التوصيات: يوصي الباحثان بتوجياه الاهتمام بإبراز الرابط أو العلاقة بين القواعد الفقهية وفروعها؛ لأن معرفة ذلك وإتقاناه يغني عن الإسهاب في

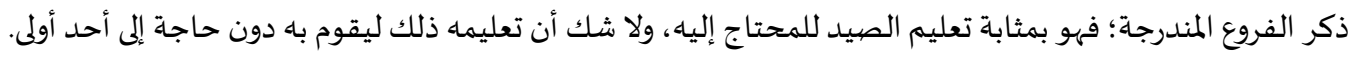

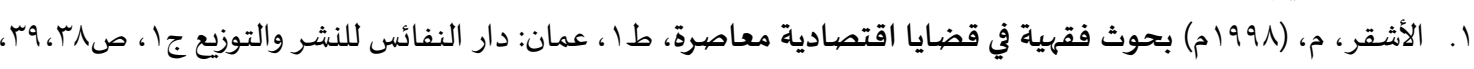
وقوله هذا مبني على اعتباره " عقدا لا اشتراكاً "

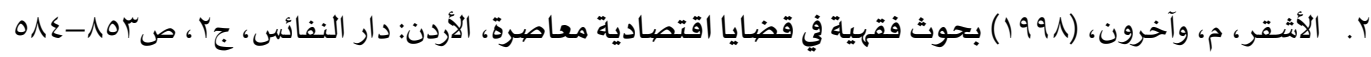

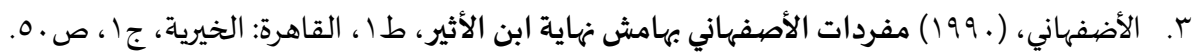

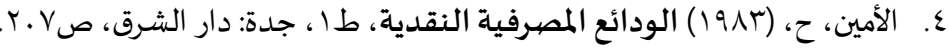

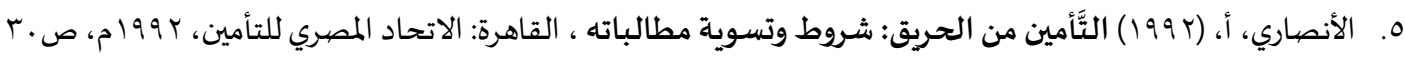

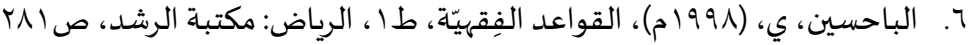

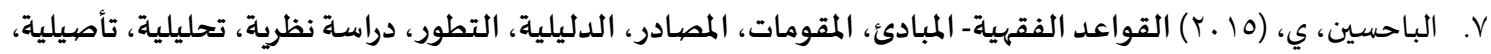

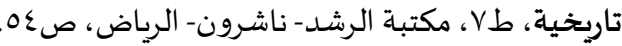

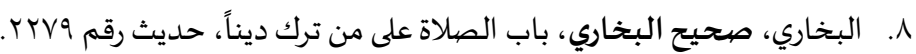

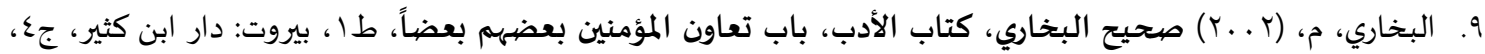

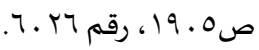

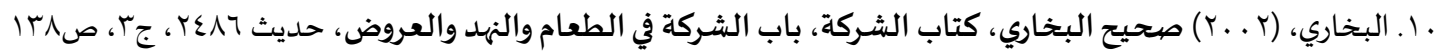

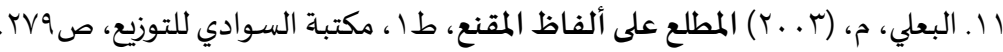

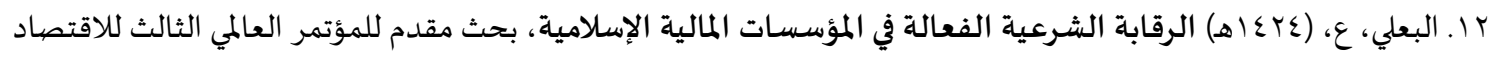
الإسلامي، الذي تنظمه كلية الشريعة والدراسات الإسلامية والمقام بجامعة أم القرى، مكة المكرمة، المملكة العربية السعودية، المبها،

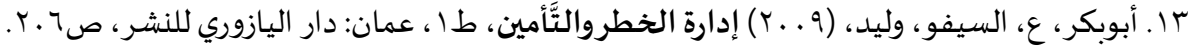

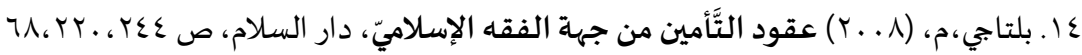

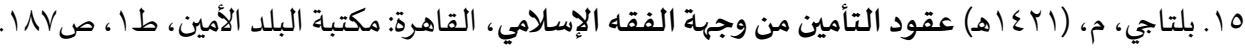




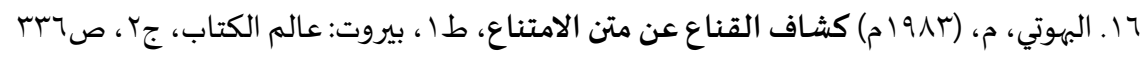

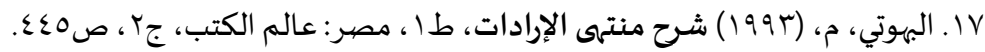

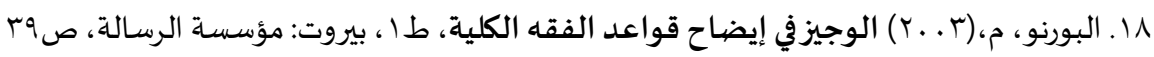

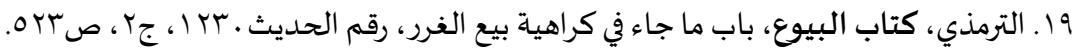

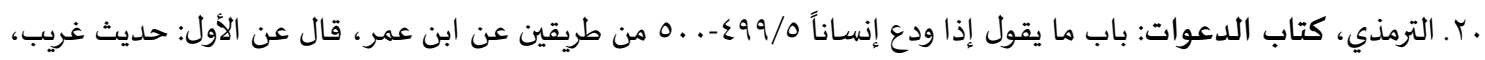

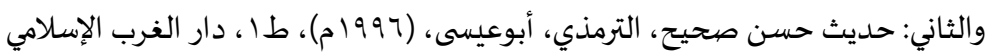

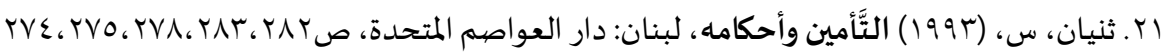

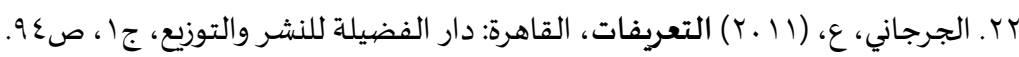

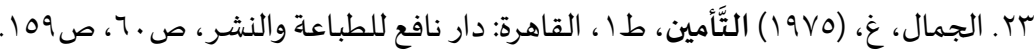

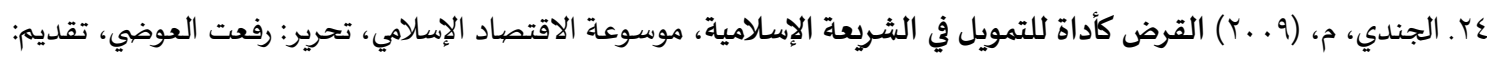

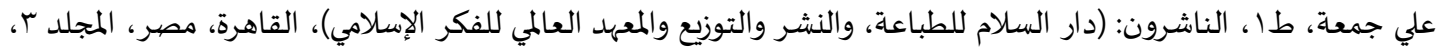
ص ص

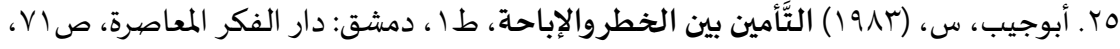

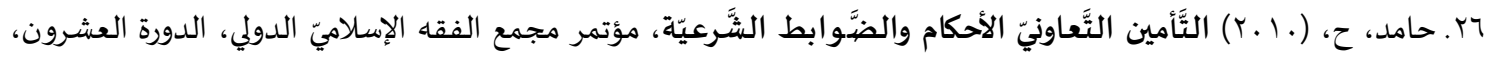
.29

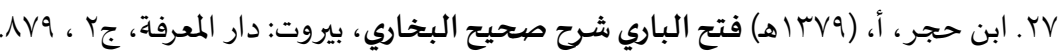

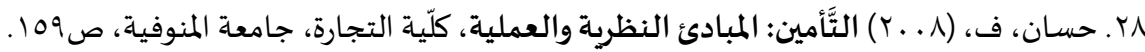

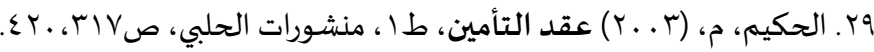

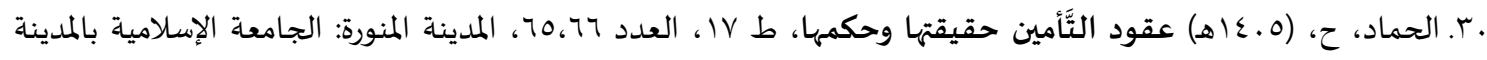
المنورة، ص97، 979

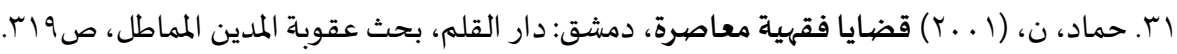

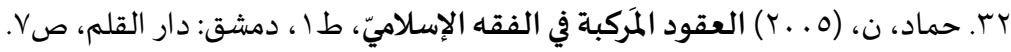
بr. الخفيف، ع، (191V) التَّأمين وحكمهه على هدي الشريعة الإسلامية وأصولها العامة، أبحاث المؤتمر الأول للاقتصاد

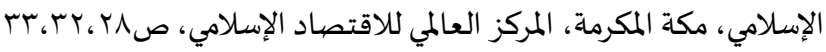

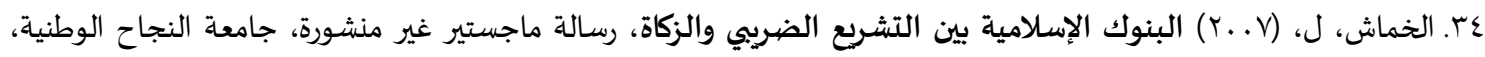

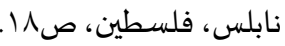

هب. داغي، ع، (9 . . ب) بحث التَّأمين التَّعاونيّ ماهيته وضـوابطه ومعوقاته، ملتقى التَّأمين التَّعاونيّ، الرياض: قاعة الملك فيصل

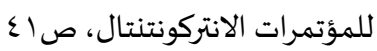

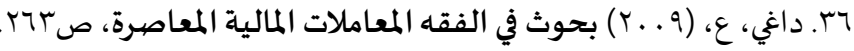

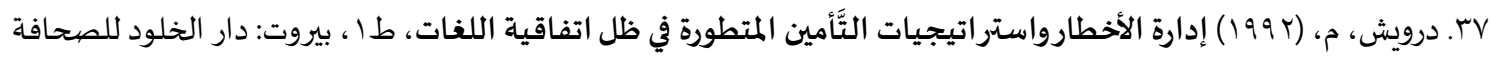

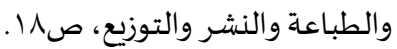

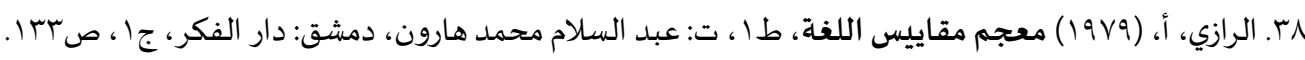

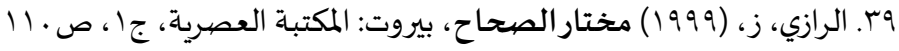

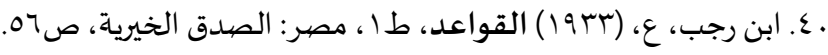

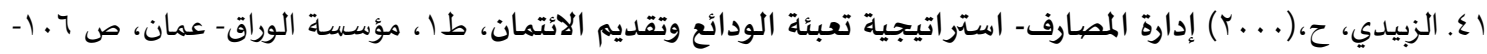
.1YO. I.V

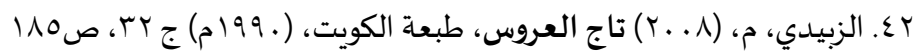

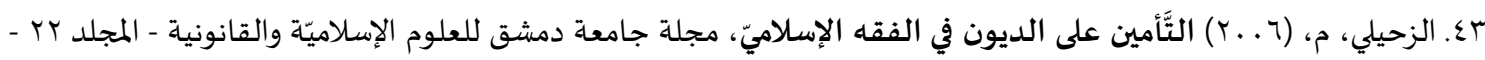

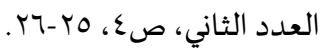

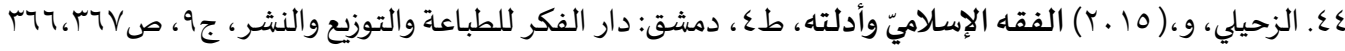

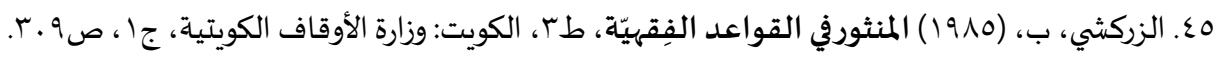




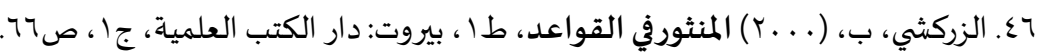

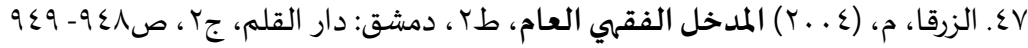

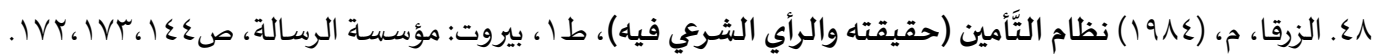

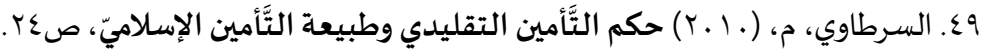

. 0.

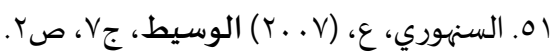

ror

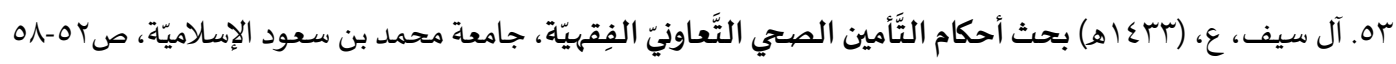

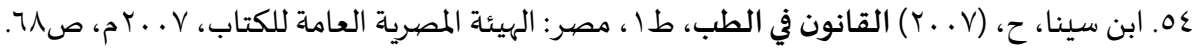

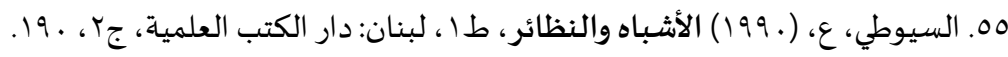
V1)

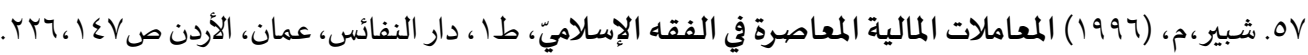

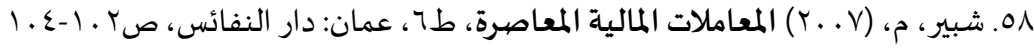

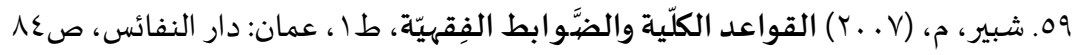

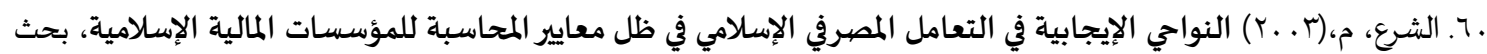

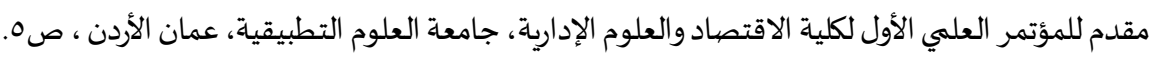

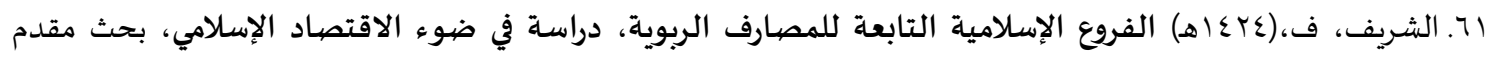

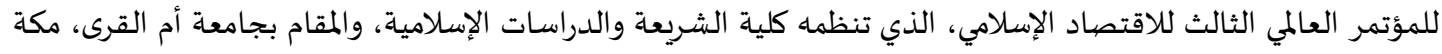

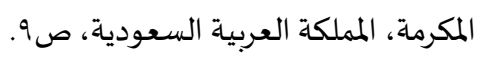

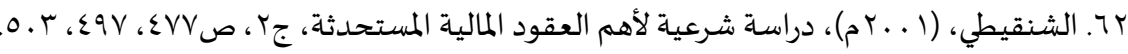

rا7. شيخ عثمان، عمر محمد فهد، إدارة الموجودات- المطلوبات لدى المصيارف التقليدية والمصهارف الإسلامية، أطروحة دكتوراه

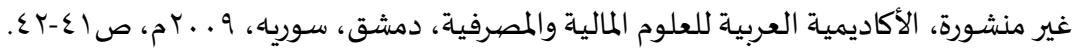

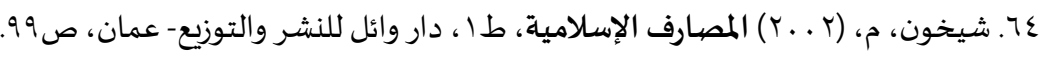

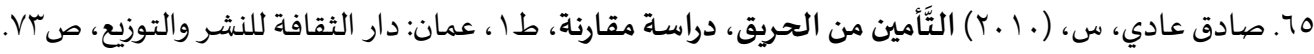

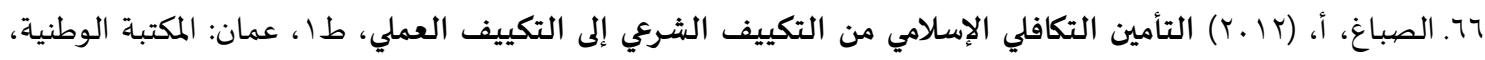

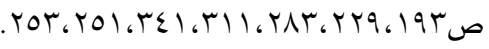

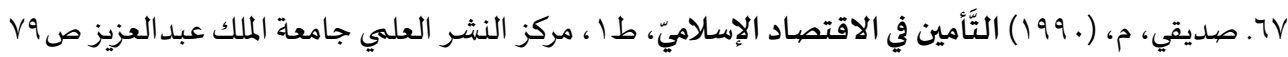

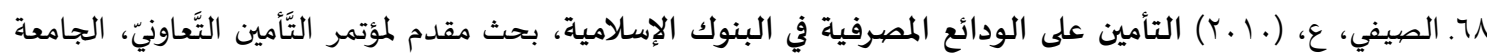

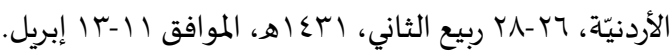

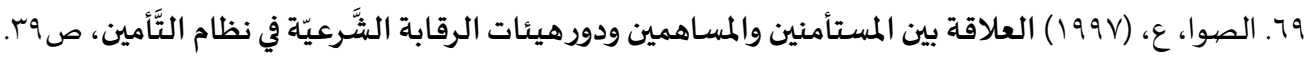

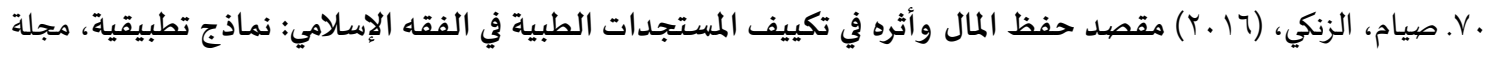

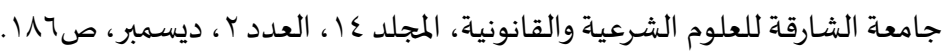

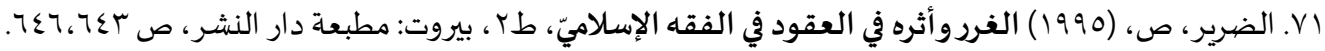

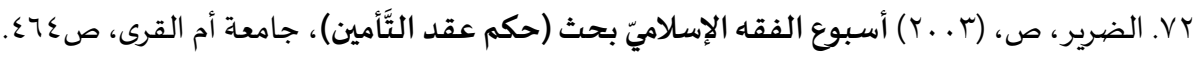

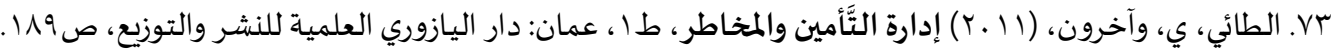

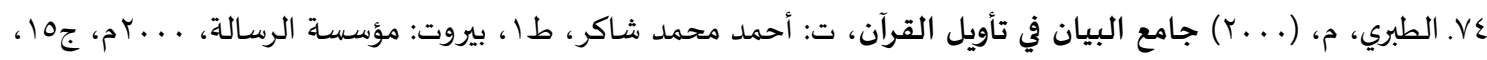
ص ص 0V. ابن عاشور، م، (ع/9 1) التحرير والتنوير "تحرير المعنى السـديد وتنوير العقل الجديد من تفسير الكتاب المجيده، تونس:

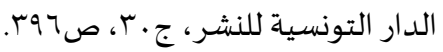

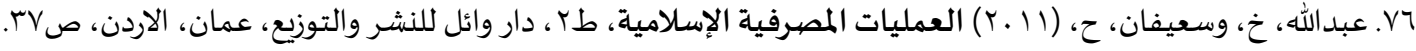




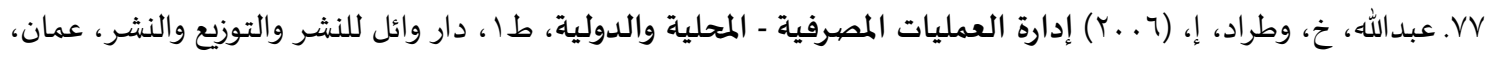

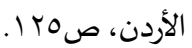

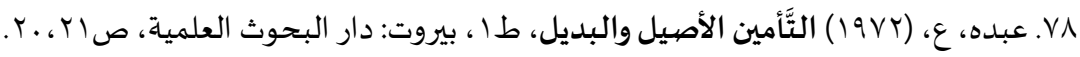

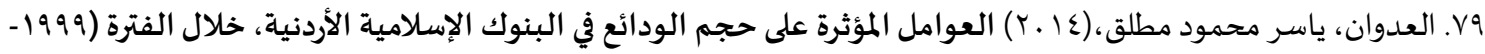

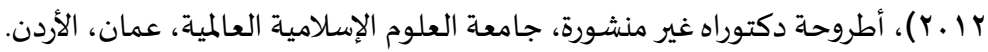

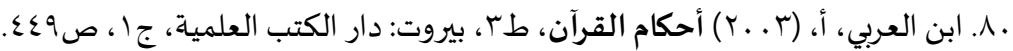

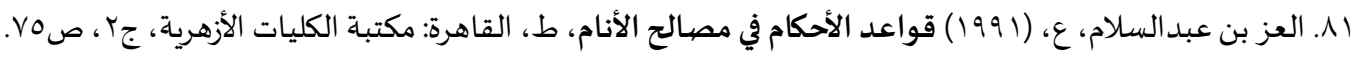

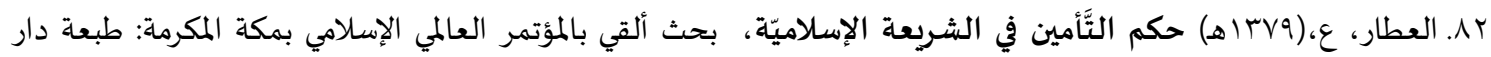

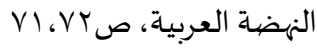

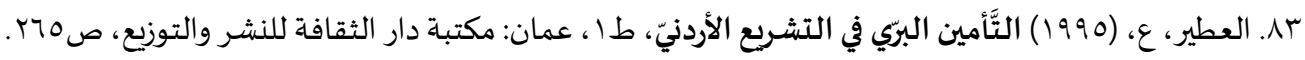

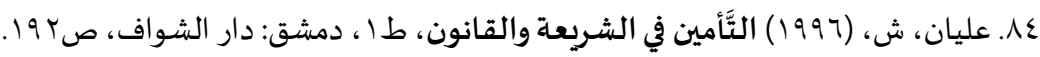

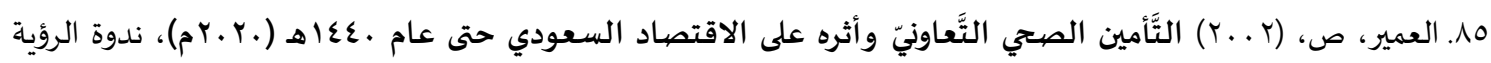

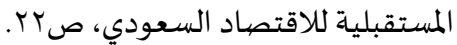

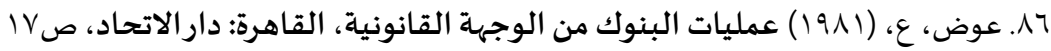

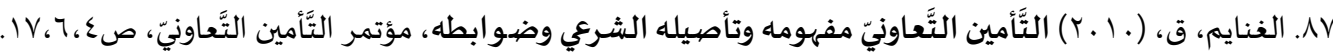

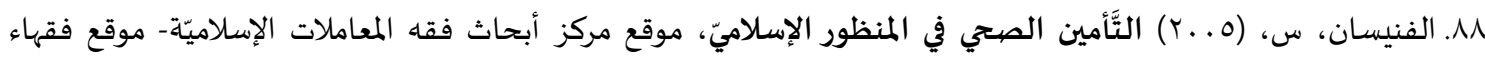

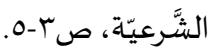

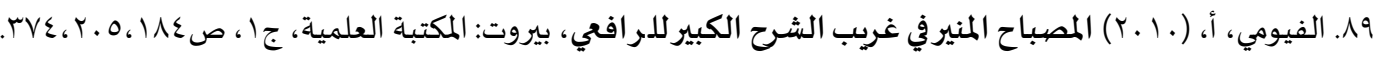

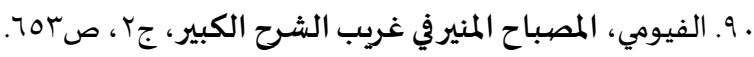

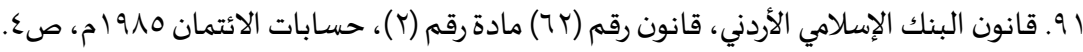

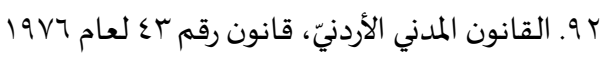

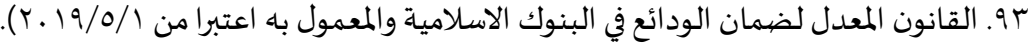

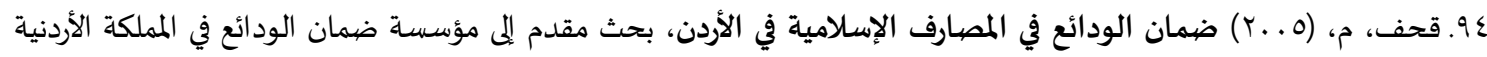

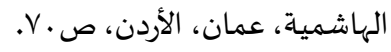

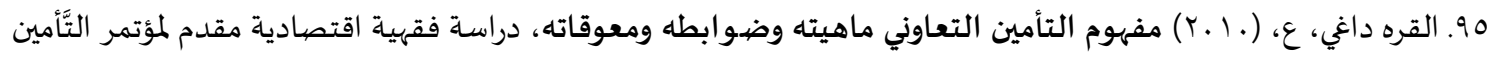

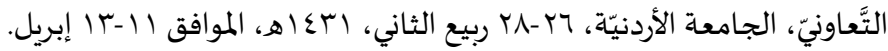

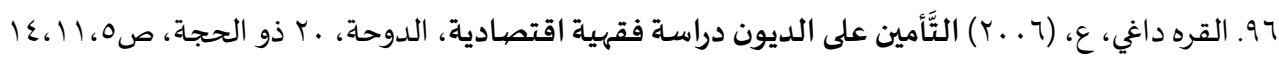

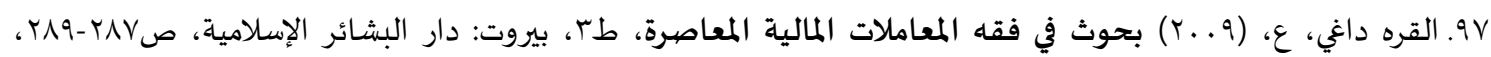
rYV,rYT, rQT.MIr

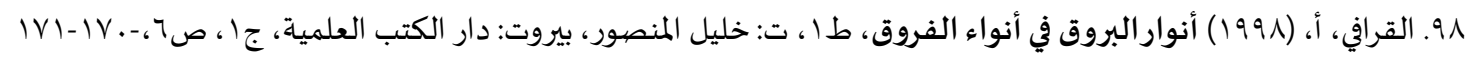

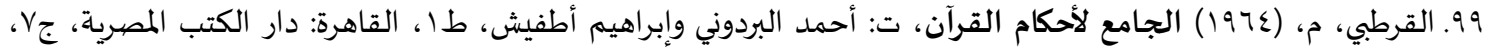
. MVY

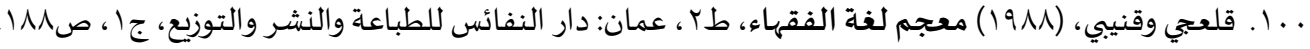

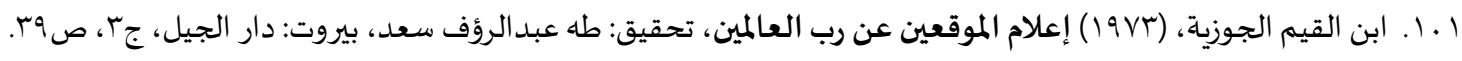

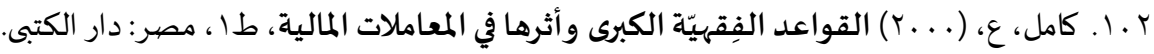

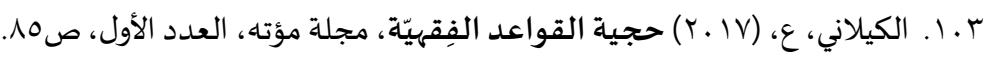

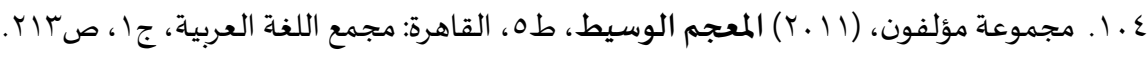

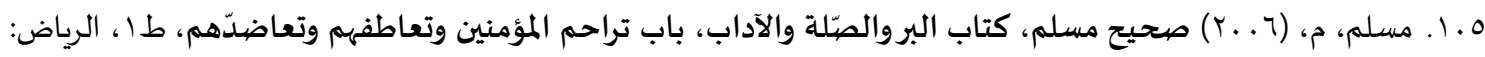

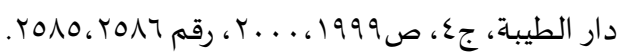

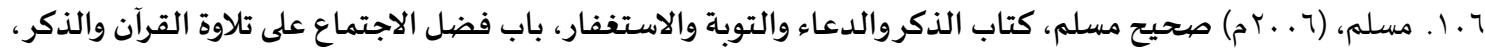
حديث رقم 


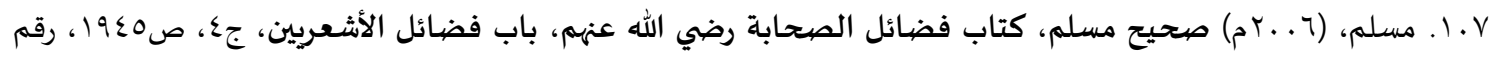
ro..

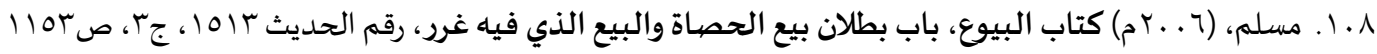

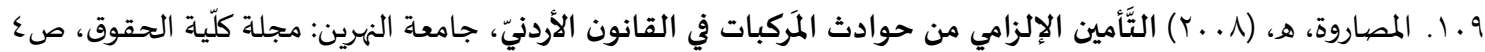

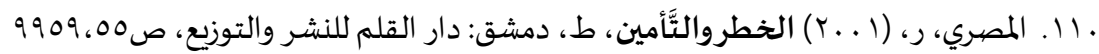

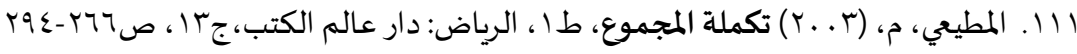

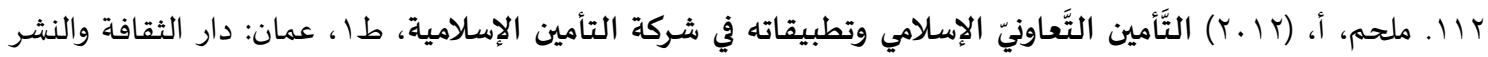

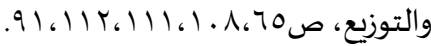

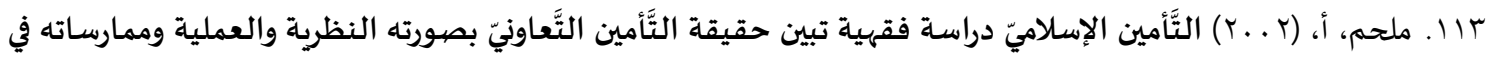

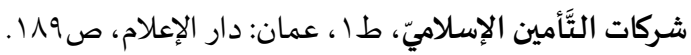

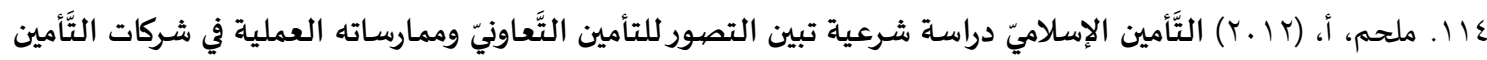

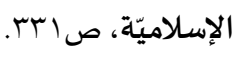

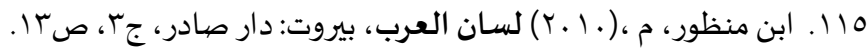

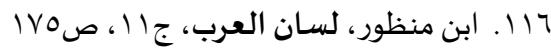

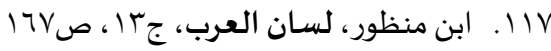

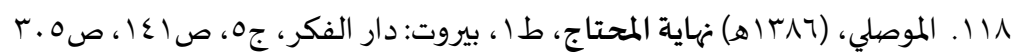

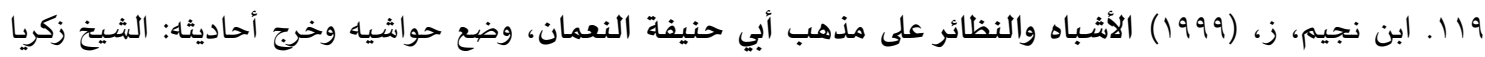

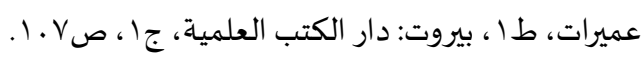

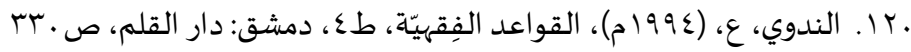

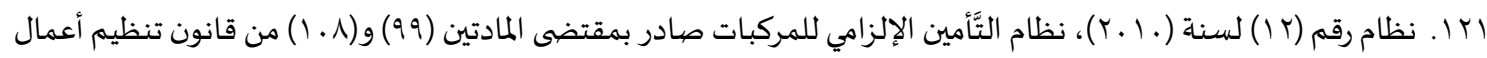

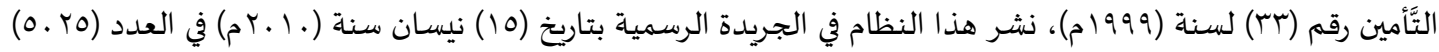
على الصفحة (Y) (Y) (Y) (19).

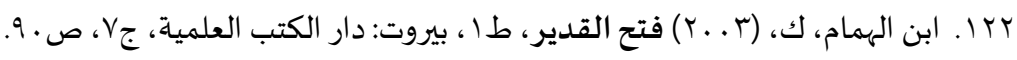

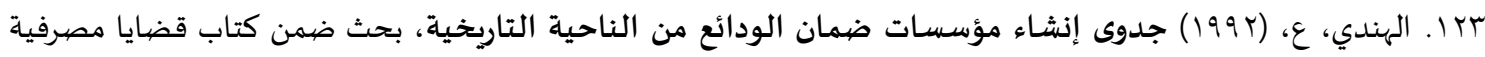

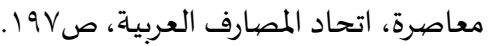


المجلة الدولية للدراسات الإسلامية المتخصصصية

International Journal of Specialized Islamic Studies (SIS)

\title{
Contemporary Applications of the Cooperative Insurance Contract in the Light of Jurisprudence Rules (Jordan Islamic Bank and Islamic Insurance Company Limited as a Model)
}

\author{
Loiy Ahmad Hasan Alsheyab \\ Training Specialist, moe, UAE \\ Loiyahmad314@yahoo.com
}

\section{Mohammad Ahmad Awad Alrawashdeh}

Professor of Jurispudence, Mutah University, Jordan

Dr-rawashdeh-60@hotmail.com

DOI: https://doi.org/DOI:10.31559/sis2020.4.1.2

\begin{abstract}
Jurisprudence rules: keeping many branches with few words, and because the branches branched, scattered and multiplied, the student needs to collect their peers.

As for cooperative insurance in general: It is a social system based on the principle of cooperation and interdependence among members of society, whose goal is to mitigate and get rid off the damages and risks to one of its members within a contract that clarifies the rights and obligations between the parties to the relationship.

And if it is legally obligatory to maintain the actions of insurance companies from falling into ambiguity and consuming people's money unlawfully, jurists have endeavored to try to correct insurance contracts issued by companies by setting the proper rules and conditions, and the jurists have relied on many means in that, jurisprudence rules have a great role And a prominent impact in this area, so this research was an attempt to collect these doctrinal rules

Which the jurists relied on to correct the actions of Islamic insurance companies from invalidity, and then to explain the practical applications practiced by both the Jordan Islamic Bank and the Islamic Insurance Company Limited - Jordan.
\end{abstract}

Keywords: Jurisprudence rules; Cooperative Insurance; Contemporary applications.

\section{References:}

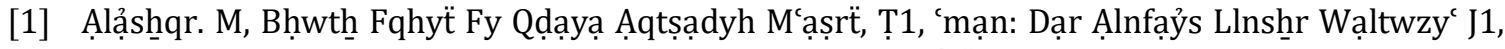
Ṣ39,38, Wqwlh Hdhạa Mbny 'la Ạ tbạrh " ‘qdạ Lạ Ạshntrạkạan “, (1998)

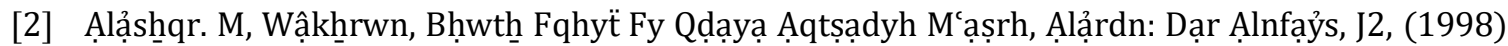
pp. 853-584

[3] Ạlạ̉ḍfhạny, Mfrdạt Ạlạ̉ṣfhạny Bhạmsh Nhạyẗ Ạbn Ạlạ̉thyyr, Ț1, Ạlqạhrh: Ạlkhyryh, J1(1990), pp.50.

[4] Ạlạ̉myn. Ḥ, Ạlwdạỷc Ạlmṣrfyh Ạlnqdyh, Ṭ1, Jdë: Dạr Ạlshrqq, (1983), pp. 207.

[5] Ạlạ̉nșạry. Ả, Ạltãạ̉myn Mn Ạlḥryq: Shrwț Wtswyẗ Mțạlbạth, Ạlqạhrh: Ạlạthạa Ạlmṣry Lltạ̉myn, (1992), pp. 30

[6] Ạlbạhsyn. Y, Alqwạ’d Ạlfiqhỹh, Ț1, Alryạd: Mktbë Ạlrsho, (1998), pp.281

[7] Ạlbạhsyn. Y, Alqwạ`d Alfqhyh- Almbạdỷ, Almqwmạt, Ạlmșạdr, Aldlylyh, Altțwr, Drạsh Nẓryh, Tḥlylyh, Tạ̉ṣylyh, Tạrykhyh, Ț7, Mktbë Ạlrsho-d- Nạsh_rwn- Ạlryạd, (2015), pp.54.

[8] Ạlbkhạary. Ṣhyḥ̣ Ạlbkhạary, Bạb Ạlṣlạh `la Mn Trk Dynạan , Ḥdyth Rqm 2279. 
[9] Albkhạry. M, Șhyh Albkhạry, Ktạb Alạ̉db, Bạb T'ạwn Ạlmw̉mnyn B'ḍhm B'ḍạan ${ }^{\mathrm{n}}$, Ṭ1, Byrwt: Dạr Ạbn Kthyr, J4, (2002), pp.1905, Rqm 6026.

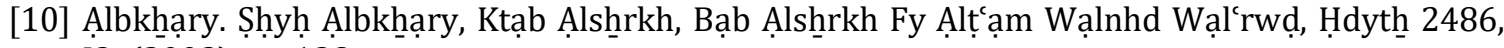
J3, (2002), pp.138

[11] Ạlb`ly. M, Ạlmțl' 'ly Ạ̉lfạz Ạlmqn`, Ț1, Mktbë Ạlswạdy Lltwzyc, (2003), pp.279.

[12] Ạlb'ly. ', Ạlrqạbh Ạlsḩrcyh Ạlfạlh Fy Almw̉ssạt Ạlmạlyh Ạlą̧slạmyh, Bḥth Mqdm Llmw̉tmr

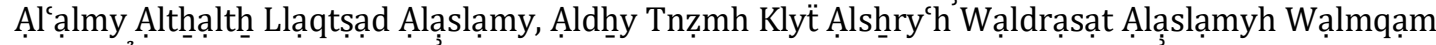
Bjạmđĕ ạ̉m Ạlqra, Mkh Ạlmkrmh, Ạlmmlkh Ạl'rbyh Ạlscwdyh, (1424h), pp.39.

[13] Ạ̉bwbkr. ', Ạlsyfw, Wlyd, Ádạrẗ Ạlkhțr Wạltãạ̉myn, Ṭ1, 'mạn: Dạr Ạlyạzwry Llnshrr, (2009), pp. 206.

[14] Bltạjy. M, 'qwd Ạltãạ̉myn Mn Jhẗ Ạlfqh Ạląslạmỹ, Dạr Ạlslạm, (2008), pp. 68,220,244

[15] Bltạjy. M, 'qwd Ạltạ̉myn Mn Wjhë Ạlfqh Ạlạslạmy, Ạlqạhrh: Mktbë Ạlbld Ạlạ̉myn, Ṭ1, (1421h), pp.187.

[16] Ạlbhwty. M, Kshạf Ạlqnạ' 'n Mtn Ạlạmtnạ', Ṭ1, Byrwt: 'ạlm Ạlktạb, J2, (1983), pp.336

[17] Ạlbhwty. M, Sh̆hḥ Mnthy Ạląrạdạt, Ṭ1, Mșr: 'ạlm Ạlktb, J2, (1993), pp.445.

[18] Ạlbwrnw. M, Ạlwjyz Fy A̧yḍạh Qwạadd Ạlfqh Ạlklyh, Ṭ1, Byrwt: Mw̉ssë̈ Ạlrsạlh, (2003), pp.39

[19] Dạghyy. ', Bḥthِ Ạltãạ̉myn Ạltãậwnỹ Mạhyth Wḍwạbțh Wm'wqạth, Mltqy Ạltãạ̉myn Ạltãcạwnỹ, Ạlryạd: Qặt Ạlmlk Fyṣl Llmw̉tmrạt Ạlạntrkwntntạl, (2009), pp.41

[20] Dạghyy. ' , Bḥwtȟ Fy Ạlfqh Ạlm’ạmlạt Ạlmạlyh Ạlm’ạṣrh, (2009), pp. 263.

[21] Drwysh. M, Adạrẗ Alaạkhhạar Wạstrạtyjyạt Ạltãạmmyn Ạlmtțwrh Fy Zl Ạtfạqyh Ạllghạt, Ṭ1, Byrwt: Dạr Ạlkhlwwd Llșhạafh Wạlțbạ hh Wạlnshrr Wạltwzyc, (1992), pp.18.

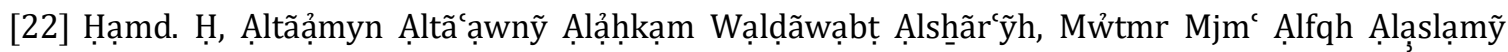
Ạldwly, Ạldwrh Ạl'shrwn, (2010), pp.49.

[23] Ạbn Ḥjr. Ạ̉, Ftḥ Ạlbạry Sh̆ḥ̣ Șhyhḥ Ạlbkhạary, Byrwt: Dạr Ạlmrfh, J2, (1379h), pp. 879.

[24] Ạlḥkym. M, 'qd Ạltạ̉myn, Ṭ1, Mnshwwrạt Ạlḥlby, (2003), pp. 420,317.

[25] Alhmạd. H, 'qwd Altãạ̉myn Hqqyqthạ Wḥkmhạ, Ṭ 17, Al'dd 65,66, Ạlmdynh Ạlmnwrh: Ạljạm'h Ạlasslạmyh Bạlmdynh Ạlmnwrh, (1405h), pp. 96,9

[26] Ḥmạd. N, Qḍayạ Fqhyh M'ạșrh, Dmsḥq: Dạr Ạlqlm, Bḥthِ ‘qwbë Ạlmdyn Ạlmmạțl, (2001), pp.319.

[27] Ḥmạd. N, Ạl'qwd Ạlmarkbh Fy Ạlfqh Ạlạslạmỹ, Ṭ1, Dmsh̨q: Dạr Ạlqlm, (2005), pp.7.

[28] Ḥsạn. F, Altãạamyn: Ạlmbạdỷ Ạlnẓryh Wạl'mlyh, KĨyë Ạltjạrh, Jạm ‘̈ Ạlmnwfyh, (2008), pp.159.

[29] Ạljmạl. Gh, Ạltãạ̉myn, Ț1, Ạlqạhrẗ: Dạr Nạf Llțbạ đë Wạlnsh̄r, (1975), pp.60, 159.

[30] Ạljndy. M, Ạlqrọ Kạ̉dạ̈ Lltmwyl Fy Ạlshry'h Ạlạslạmyh, Mwswđë Ạlạqtșạd Ạlạslạmy, Tḥryr: Rf't

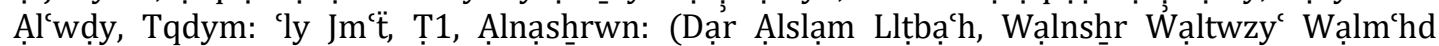
Ạl'ạlmy Llfkr Ạląslạmy), Ạlqạhrh, Mṣr, Ạlmjld 3, (2009), pp.242.

[31] Ạljrjạny. ', Alttryfạt, Ạlqạhrh: Dạr Ạlfḍylh Llnsḥr Wạltwzy', J1, (2011), pp.94.

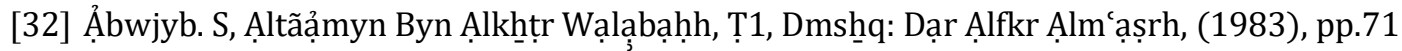

[33] Alkhfyf. ', Altãạ̉myn Whkmh 'la Hdy Ạlshry'h Ạlaslạmyh Wạ̉ṣwlhạ Al'ạmh, Ạ̉bhạth Ạlmw̉tmr Ạlậwl Llạqtșạd Ạlạslạmy, Mkh Ạlmkrmh, Ạlmrkz Ạl'ạlmy Llạqtșạd Ạlạslạmy, (1987), pp. $33,32,28$

[34] Ạlrạzy. Ạ̉, Mcjm Mqạyys Ạllghhh, Ṭ1, T: 'bd Ạlslạm Mḥmd Hạrwn, Dmshq: Dạr Ạlfkr, J1, (1979) pp.133.

[35] Ạlrạzy. Z, Mkḥtạr Ạlșhạḥ̣, Byrwt: Ạlmktbh Ạl'ṣryh, J1, (1999), pp.110

[36] Ạbn Rjb. ', Alqwạacd, Ț1, Mșr: Ạlșdq Ạlkhyryh, (1933), pp.56. 
[37] Ạlsnhwry. ', Mṣạdr Ạlḥq Fy Ạlfqh Ạląslạmy, Lbnạn: Dạr A̧hyạ’ Ạltrạthِ Ạl'rby, J3, (1997), pp.196 277.

[38] Ạlsrțạwy. M, Ḥkm Ạltãạ̉myn Ạltqlydy Wṭbyđë Ạltãạ̉myn Ạlạslạmỹ, (2010), pp.24.

[39] Thnnyạn. S, Ạltãạ̉myn Wạ̉hkạmh, Lbnạn: Dạr Ạl'wạșm Ạlmtḥdh, (1993), pp. 274,275,278,283,282

[40] Ạltrmdhyy. Ktạb Ạlbyw'c, Bạb Mạ Jạ’ Fy Krạhyẗ By’ Ạlgȟrr, Rqm Ạlḥdythַ1230, J2, pp.523.

[41] Ạltrmdhy. Ktạb Ạld'wạt: Bạb Mạ Yqwl Ạdhạ Wd' Ansạnạan 5/499-500 Mn Țryqyn 'n Ạbn 'mr,

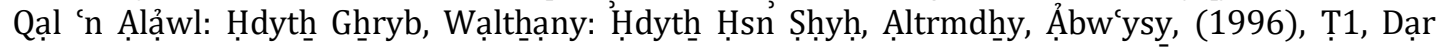
Ạlghrb Ạląslạmy

[42] Ạlzbydy. H, Adạrẗ Ạlmșạrf- Ạstrạtyjyh Tcbỷt Ạlwdạỷ Wtqdym Ạlạỷtmạn, Ṭ1, Mw̉ssẗ Ạlwrạq'mạn, (2000), pp. 106-107,125.

[43] Ạlzbydy. M, Tạj Ạl'rws, Ṭbđ̈ Ạlkwyt, J 32, (2008), pp. 185

[44] Ạlzhyly. M, Ạltãạ̉myn 'la Ạldywn Fy Allfqh Ạlạslạmỹ, Mjlë Jạmđ̈̈ Dmsḥq Ll'lwm Ạlạslạmỹh Wạlqạnwnyh - Ạlmjld 22 - Ạl'dd Ạlthạny, (2006), pp.4, 25-26

[45] Ạlzhyly. M, Ạltãạ̉myn 'ly Ạldywn Fy Ạlfqh Ạląslạmỹ, Mjlẗ Jạm‘̈̈ Dmsḥq Ll'lwm Ạlạslạmỹh Wạlqạnwnyh - Almjld 22 - Al'dd Althạny, (2006), pp.4, 25-26.

[46] Ạlzhyly. W, Ạlfqh Ạląslạmỹ Wạ̉dlth, Ț4, Dmshqu: Dạr Ạlfkr Llțbậh Wạltwzyc Wạlnsȟr, J9, (2015) pp.366,367

[47] Ạlzrkshyy. B, Ạlmnthֵwr Fy Ạlqwạcd Ạlfiqhỹh, Ț3, Ạlkwyt: Wzạrẗ Ạlạ̉wqạf Ạlkwytyh, J1, (1985), pp. 309.

[48] Ạlzrkshyy. B, Ạlmnthֵwr Fy Ạlqwậd, Ț1, Byrwt: Dạr Ạlktb Ạl'lmyh, J1, (2000), pp.66.

[49] Ạlzrqạ. M, Ạlmdkh̆l Ạlfqhy Ạl'ạm, Ț2, Dmshqq: Dạr Ạlqlm, J2, (2004), pp. $948-949$

[50] Ạlzrqạ. M, Nzạm Ạltãạ̉myn (Ḥyqth Wạlrạ̉y Ạlsh̆ry Fyh), Ṭ1, Byrwt: Mw̉ssï Ạlrsạlh, (1984), pp. $172,173,144$. 